\title{
Wadi Fatima Thin-Skinned Foreland FAT Belt: A Post Amalgamation Marine Basin in the Arabian Shield
}

\author{
Zakaria Hamimi $^{{ }^{*}}$, Mohamed Matsah ${ }^{1}$, Mohamed El-Shafei ${ }^{1,2}$, Abdelhamid El-Fakharani ${ }^{1,3}$, \\ Abdulrahman Shujoon ${ }^{1}$, Majid Al-Gabali ${ }^{1}$ \\ ${ }^{1}$ Department of Structural Geology and Remote Sensing, Faculty of Earth Sciences, King Abdulaziz University, Jeddah, Saudi Arabia \\ ${ }^{2}$ Geology Departments, Faculty of Science, Suez Canal University, Ismailia, Egypt \\ ${ }^{3}$ Geology Department, Faculty of Science, Aswan University, Aswan, Egypt \\ Email: *yahiahamimi@gmail.com
}

Received June 9, 2012; revised July 6, 2012; accepted August 7, 2012

\begin{abstract}
Wadi Fatima fold-thrust (FAT) belt is a distinctive foreland FAT belt in the Arabian-Nubian Shield (ANS) involving unmetamorphosed to slightly metamorphosed sedimentary sequence of Fatima Group, deposited over a metamorphic/igneous basement, comprising ortho-amphibolites, orthoand para-schists (with chaotic unmappable blocks of marbles, pyroxenites and metagabbros), older granite (773 $\pm 16 \mathrm{Ma}$ ) and younger granite. The basement exhibits structural fabrics, such as attenuated tight isoclinal folds, sheared-out hinges, NE-SW penetrative foliation and subhorizontal stretched and mineral lineations, related to an oldest prominent dextral shearing phase affected the main Wadi Fatima during the Neoproterozoic. In Wadi Fatima FAT belt, the style of deformation encompasses flexural-slip folding forming mesoscopicand map-scales NE to ENE plunging overturned antiforms and synforms, and a thrust duplex system bounded by floor thrust and sole thrust (basal detachment) dipping gently towards the hinterland (SE to SSE direction) and rises stratigraphically upwards towards the foreland. Such style is affiliated to thin-skinned deformation. Several lines of evidence, such as geometry of interacting outcropand map-scale folds and thrusts, patterns of thrust displacement variations and indications for hinge migration during fold growth, strongly suggest that folding and thrusting in Wadi Fatima FAT belt are geometrically and kinematically linked and that thrusting initiated as a consequence of folding (fold-first kinematics). Thrusts frequently show flat-ramp-flat geometry, and every so often give an impression that they are formed during two main sub-stages; an older sub-stage during which bedding sub-parallel thrusts were formed, and a younger sub-stage which generated younger ramps oblique to bedding. Thrust ramps with SE to SSE dipping regularly show sequential decrease in dip or inclination (due to piggy-back imbrication) into their transport direction which is proposed to be towards NW to NNW. Evidence indicating this transport direction of Wadi Fatima FAT belt embrace NW to NNW oriented stretching lineations recorded along thrust planes, NW to NNW folding vergence, and diminishing of the intensity of deformation and thrust stacking and imbrication from SE to NW; i.e. from hinterland to foreland. The tectonic transport vector is congruent with the mean orientation of slickenline striae formed by layer-parallel slipping along folded bedding planes. The mean orientation of slickenline lineations, after their host beds were rotated to horizontal about their strikes, is found to be $\mathrm{N} 25^{\circ} \mathrm{W}-\mathrm{S} 25^{\circ} \mathrm{E}$. Two tectonic models are proposed to unravel the structural history of the study area and to illustrate the tectonic evolution of Wadi Fatima FAT belt which represents one of interesting foreland FAT belts recorded worldwide. In the first model, the area was evolved from dextral shearing during the early convergence and amalgamation between East and West Gondwana, to emplacement of the older granite during a period of crustal cessation and relaxation, NNW SSE extension and extrusion of dyke swarms, emplacement of younger granite, deposition of Fatima Group over an ancient peneplain, layer parallel shortening, folding and fold tightening and overturning, thrusting, NE-SW (to NNE-SSW) shortening, and eventually NE tilting accompanied with Red Sea rifting (?). The second model suggests the presence of basement ramps (pre-existing normal faults), with NW to NNW dipping, have a strong effect on overlying Fatima Group which was evolved throughout gravitational, soft-sediment slumping and deformation.
\end{abstract}

Keywords: Fold-Thrust Belt; Fatima Group; Piggy-Back Imbrication; Deformation

\section{Introduction}

The Arabian-Nubian Shield (ANS) is a collage of Neoproterozoic juvenile arcs, younger sedimentary and volcanic basins, voluminous granitoid intrusions, and en- claves of pre-Neoproterozoic crust that crop out in the western Arabian Plate and the northeastern African Plate at the northern end of the East African Orgen (EAO); [1-4]. Despite their abundance and, locally, great thick- 
ness, relatively little is known about the development and depositional environments of the younger sedimentary and volcanic basins [5]. Fundamental unanswered questions concern 1) the causes of subsidence that created the basins, whether thermal contraction, loading or flexure downwarping, or extension and pullapart development in strike slip systems; 2) the apparent genetic relationships between basin formation and local and regional structures such as strike-slip faulting and mantle doming; 3) the relationship between basin formation and granitoid magmatism; 4) the extent to which some of the basins were originally interconnected; 5) which basins were marine or connected to a late Cryogenian-Ediacaran ocean; and 6) whether any basins contain unequivocal Ediacaran multicellular fossils [5].

Wadi Fatima, near Jeddah, Saudi Arabia, is a large fault-controlled volcanosedimentary post-amalgamation basin, exhibiting most of the essential features of marine basins. With the exception of the work done by [6] on Jabal Abu Ghurrah in the NE side of Wadi Fatima, it is astonishing to refer here that in despite the importance of this area from the tectonic point of view, over and above the ease of its accessibility, it was not the subject of detailed structural or tectonic studies before. [7] published a detailed study on the sedimentary sequence exposed between Jeddah and Makkah in the areas of Wadi Fatima and environs, including the study area. The leading work of [8] threw light only on the general geology of the whole district, with emphasis on lithostratigraphic characteristics of Fatima Formation. These authors constructed a geologic map at a scale of 1:50,000 and classified the exposed rocks into four groups, separated by unconformities: Pre-Fatima basement (Precambrian), Fatima Formation (Upper Precambrian-Infracambrian), Shumaysi Formation (Oligocene) and Neogene (?). Fatima Formation [9], former "Série du Wadi Fatima” [10], is subdivided into three main units; lower clastic unit (green color), middle carbonate unit (yellowish white color) and upper clastic unit (red color). Age of Fatima Formation is estimated as $675 \pm 17 \mathrm{Ma}$ by [11] and $688 \pm$ 30 Ma by [12,13] compiled a geologic map for Makkah Quadrangle as a whole at a scale of 1:250,000. In their explanatory notes the authors indicated that Fatima Group (former Fatima Formation) is preserved in NEtrending synclines that rest unconformably on a asement consisting of Samaran Formation, the Rumayda granite, the Samd tonalite, and the Kamil Suit on the northwestern side of Wadi Fatima, and in the north of the mapped sector in the Wadi Ghurrah. The authors classified this group into three formations (from base to top); Baqqar Formation, Shubayrim Formation and Daf Formation. [6] pointed out that the uppermost Precambrian sediments and volcanics of Fatima Group exposed at Jabal Abu Ghurrah were deformed by NNWSSE tangen- tial compression. According to the authors, the sequence of events in Jabal Abu Ghurrah began with the development of intra-bed folds and thrusts. In the second event, the area was deformed by an ENE to NE plunging overturned syncline. During the third structural event, continued deformation of the area by the same tangential compression was evident and led to the development of low-angle thrusts. [14] believed that Fatima Group lies uncomfortably over Samaran Group and consists of three parts; the lower part has a basal conglomerate overlain by volcanic andesites, agglomerate and tuffs; the middle part is formed of stromatitic marble, sandstone and red slate; and the upper part consists of a succession of ignimbrites. Based mainly on the previously mentioned work carried out by $[13,15]$ described the general geology and lithology of the Neoproterozoic Fatima Group and came to the conclusion that this Group has developed on the line of a major SW-trending fault system known as the Fatima structural zone; the zone is the most prominent and longest-lasting structural feature in the Jeddah area having been in existence since Precambrian times. The author believed that this structural zone was probably re-activated in Tertiary times due to sea-floor spreading in the Red Sea and is the site of present-day microseismic activity. [16] shed light on the kinematics and progressive deformation history of AlJammom PanAfrican belt which represents the northeastern extension of the basement cropping out in the present study area. The authors described the area as a NE-trending shear zone evolved through a multiple tectonic events and shearing gave rise to an imbricate thrust stack. [14] published a textbook on the geology of the Arabian Shield of Saudi Arabia, presented the three classifications that have been proposed to discuss the evolution of the shield rocks $[17,18]$ and carried out a correlation between Arabian and Nubian Shields. Wadi Fatima Group was described in the first classification with Ablah Group belonging to Middle Sequences. The two sedimentary parts, the lower and the middle were correlated with those of Ablah Group, while the volcanics forming the upper part of Fatima Group were considered contemporaneous with the "Upper Layered Sequences" in the third classification. [19] stated that the structures of Wadi Fatima area are mainly represented by detachment folds, ramp anticlines and passive roofed duplexes at both mapand metricscales. Cross sections crosscutting the overall structures allow these authors to decipher a doubly vergent thrust system of Precambrian age and to suppose that the area has suffered a negative structural inversion during OligoMiocene outlined normal faults intersecting at right angle the previous structures and related the Red Sea opening.

The present study is devoted to study the Neoproterozoic (Late-Proterozoic) Fatima Group in its type locality near Jeddah City which represents one of some forty 
post-amalgamation volcano-sedimentary basins in the ANS and also one of interesting foreland FAT belts recorded worldwide. The mapped area is bounded by long. $39^{\circ} 28^{\prime} 24.06^{\prime \prime}$ and $39^{\circ} 42^{\prime} 2.457^{\prime \prime} \mathrm{E}$ and lat. $21^{\circ} 24^{\prime} 49.67^{\prime \prime}$ and $21^{\circ} 39^{\prime} 4.11^{\prime \prime N}$ (Figure 1). The study aims to add much more insights into the body of data that constrains the deformation history of the shield rocks. It discusses the tectonic setting of the greater Wadi Fatima District within the frame of recently accepted plate tec-tonic models proposed for the evolution of the ANS, describes the relation of Fatima Group to the other basement rocks and presents details on the styles, geometries and kinematics of both folding and thrusting that playing a noteworthy role in the structural shaping of the whole Wadi Fatima District.

\section{Geologic Setting}

The area of study represents a part of the Greater Wadi Fatima District. The exposed rocks cropping out in the mapped area $\left(689.13 \mathrm{~km}^{2}\right)$ are almost entirely of Neoproterozoic age and could be classified into two main units: preFatima basement and Fatima Group (Figures 2-5); contact separating both units is unconformity surface. Post-Fatima rocks are locally encountered in the area and affiliated to Shumaysi Formation (Oligocene to Neogene sediments) that resting nonconformably over the Neoproterozoic rocks.

\subsection{Pre-Fatima Basement}

The pre-Fatima basement rocks are represented mainly by gneisses and amphibolites, schists, gabbros, and older and younger-granites, in addition to andesites, locally intruded by rhyolites and dykes of mafic composition.

\subsubsection{Gneisses and Amphibolites}

The gneisses and amphibolites form a NE-SW trending narrow belt exposed along the northwestern flank of the main Wadi Fatima. The gneisses are less abundant and exhibiting banding. Under the microscope, they exhibit ortho-origin and composed essentially of quartz, plagioclase and biotite, together with secondary epidote and chlorite and accessory opaques and zircon. The amphibolites are grey to dark grey in color, fine grained and showing preferred orientation of amphibole and plagioclase feldspar minerals. Because of the presence of Quaternary fan deposits and alluvial wadi fillings, the contact of the amphibolites versus other rock units is difficult to be detected, except in nearly one location in Jabal Daf (Figure 6(a)). The amphibolites are foliated, sheared, brecciated, occasionally folded and partly migmatized. In places, they are intruded by younger granite, traversed by mafic dykes and invaded by quartz veins. Microscopi-

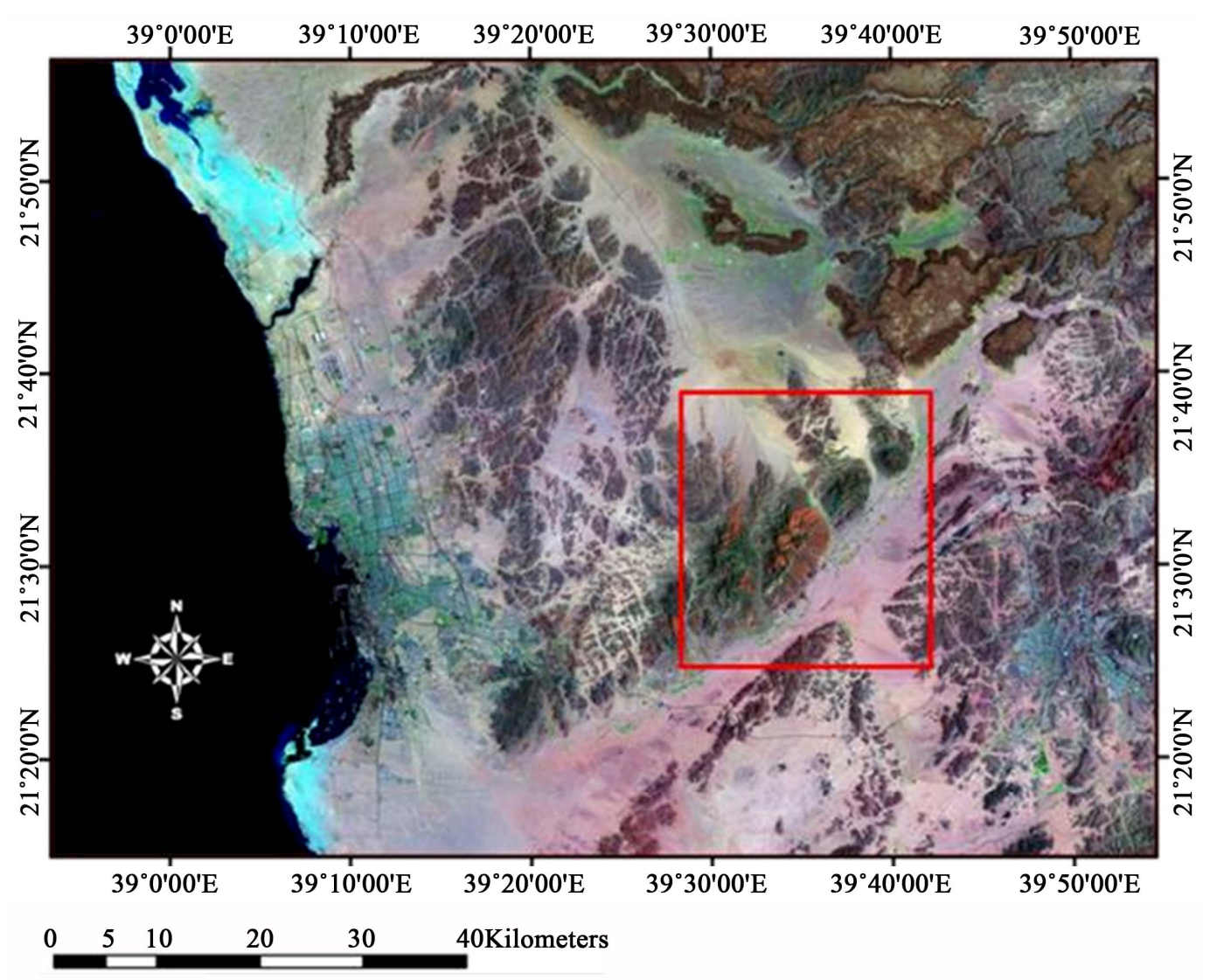

Figure 1. A landsat image showing the main Wadi Fatima and the area of study. 


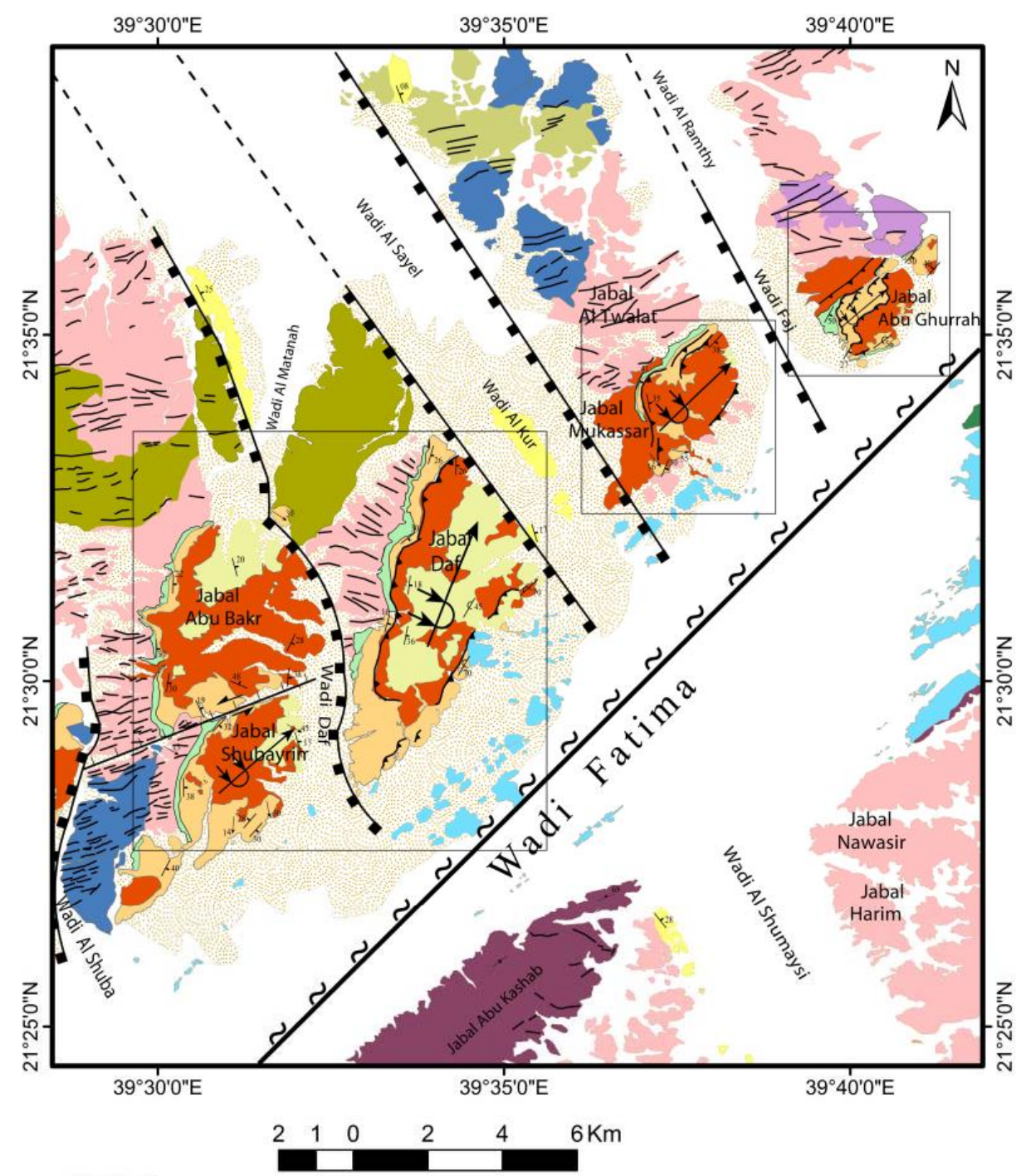

Legend

\section{LITHOLOGIES}
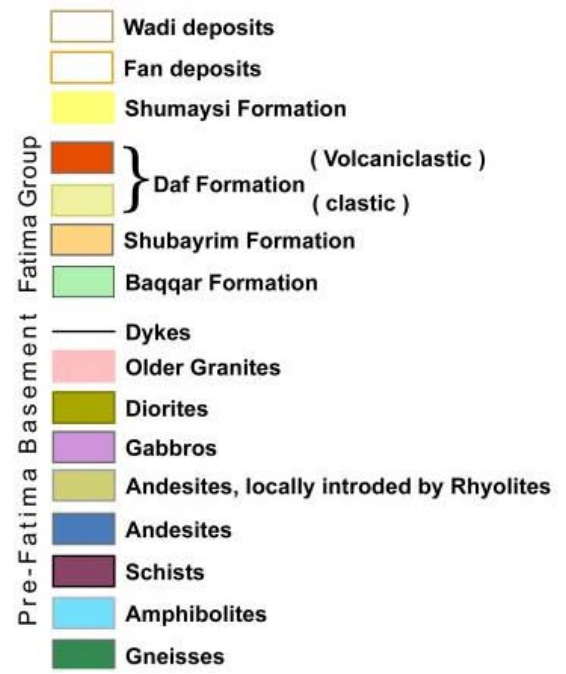

\section{STRUCTURAL ELEMENTS}

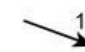

Bedding plane - slickenline

$\multimap \quad$ Vertical foliation

80 Strike and dip of foliation

Strike and dip of foliatir

overturned bedding

$/_{15} \quad$ Strike and dip of bedding

$\stackrel{\downarrow \downarrow}{\longrightarrow} \quad$ Plunging overturned syncline

$\stackrel{\leftarrow}{\longrightarrow}$ Diagonal slip fault

Listric normal fault

^. Thrust fault

$\sim \quad$ Wadi Fatima Shear Zone

Figure 2. Geologic map of the area bounded by long $39^{\circ} 28^{\prime} 24.06^{\prime \prime}$ and $39^{\circ} 42^{\prime} 2.457^{\prime \prime} \mathrm{E}$ and lat. $21^{\circ} 24^{\prime} 49.67^{\prime \prime}$ and $21^{\circ} 39^{\prime} 4.11^{\prime \prime} \mathrm{N}$, Wadi Fatima District, west-central part of the Arabian Shield. Boxes refer to areas mapped in Figures 3-5. 


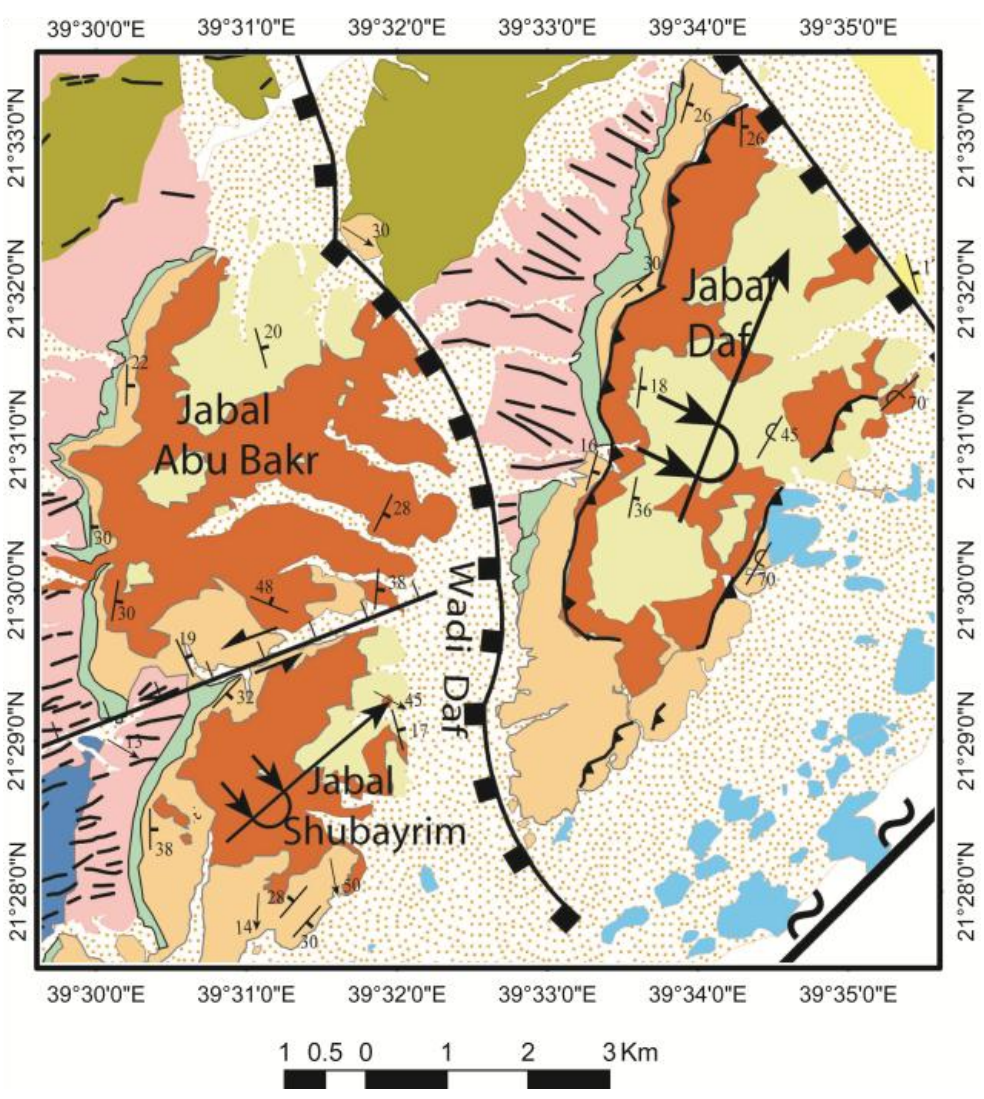

Figure 3. A large-scale geologic map of Jabal Abu Ghurrah area. Symbols as in Figure 2.

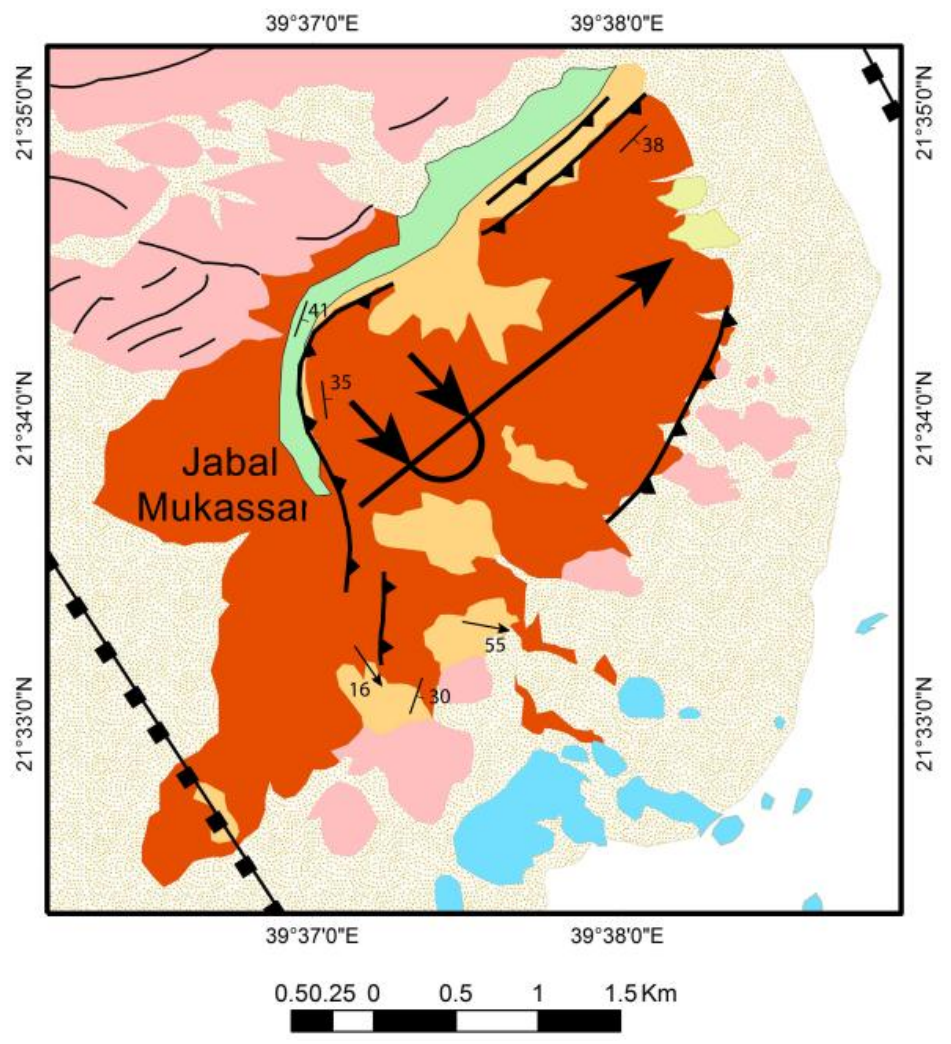

Figure 4. A large-scale geologic map of Jabal Mukassar area. Symbols as in Figure 2. 


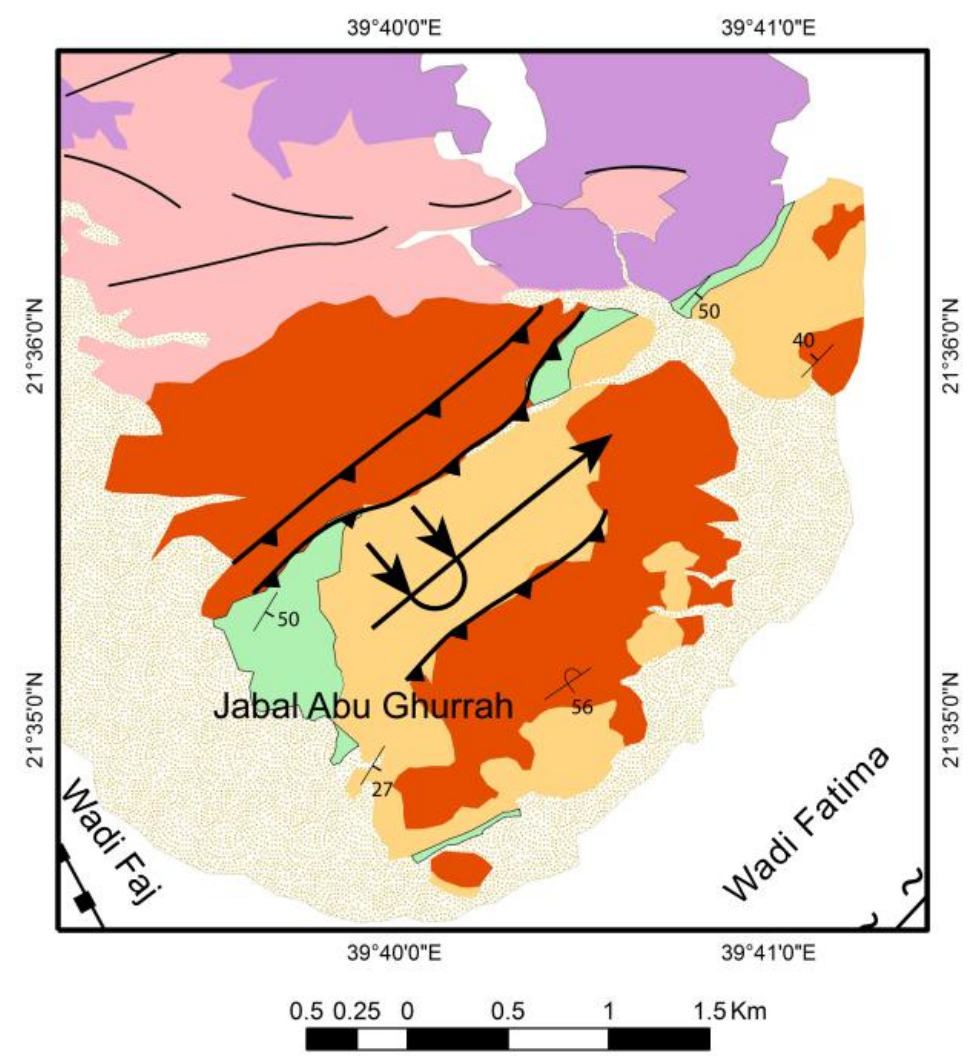

Figure 5. A large-scale geologic map of Jabal Daf area. Symbols as in Figure 2.

cally, the amphibolites consist fundamentally of preferably oriented crystals of hornblende, plagioclase and quartz, together with epidote, calcite and opaques (Figure 6(b)). Some amphibolites are formed of actinolite and/or cummingtnite instead of hornblende. Others display mimetic texture marked by rotated plagioclase porphyroclasts surrounded by dark fine-grained matrix of amphiboles.

\subsubsection{Schists}

The schists cover immense domain along the southeastern flank of the main Wadi Fatima and extend further southeast and east of the mapped area for several kilometers (Figure 6(c)). No direct relationship of the schists to other basement rocks can be distinguished, except that locally the schists are intruded by granitic rocks and pegmatites and invaded by quartz veins. These intrusions either occur as off-shoots and apophysis crosscutting the foliations planes of the schists or tectonically intermingling with the schists forming typical migmatite in which the paleosome is the schist and the neosome is the granites and pegmatites. Moreover, unmappable chaotic blocks of marbles, hornblendite and metagabbro are infrequently recorded within the schists. These blocks show most of the essential features of the ophiolitic blocks encountered elsewhere in the ANS. Petrographically, the schists are discriminated into two main types; orthoand para-schists.
The ortho-schists are manifested by chloriteand actionlite-hornblende-schists, whereas the para-schists are represented by sericites-chist.

\subsubsection{Andesites, Locally Intruded by Rhyolites}

The pre-Fatima basement encompasses slightly metamorphosed to unmetamorphosed volcanic rocks, representing by andesites and its pyroclastics, together with rhyolites. The andesites are dominant and sometimes being extruded by dyke swarms of rhyolites to a degree that it is impossible to separate the two rock units. For this reason, both types of volcanic rocks are dealt with under the title "andesites, locally intruded by rhyolites" in the geologic map. The andesites are encountered near the upstream head of Wadi Al-Shuba, covering vast domain along the western flank of the wadi. They are located also in the area bounded by Wadi Al Ramthy and Wadi Al Sayel, just to the north of Jabal Al Twalat. They are remarkably older than the gabbros and older granites, where roofpendants and xenoliths of andesites occur in these plutonic rocks. On the other hand, they have no relation to the volcanic flows, sills and dykes belonging to the Fatima Group. On exposure-scale, the pre-Fatima andesites are deformed, being well foliated and exhibiting rodding and pencil-like lineations. On handspecimenscale, the andesites are fineto very fine-grained, darkgreen to greenish grey in color and infrequently contain 

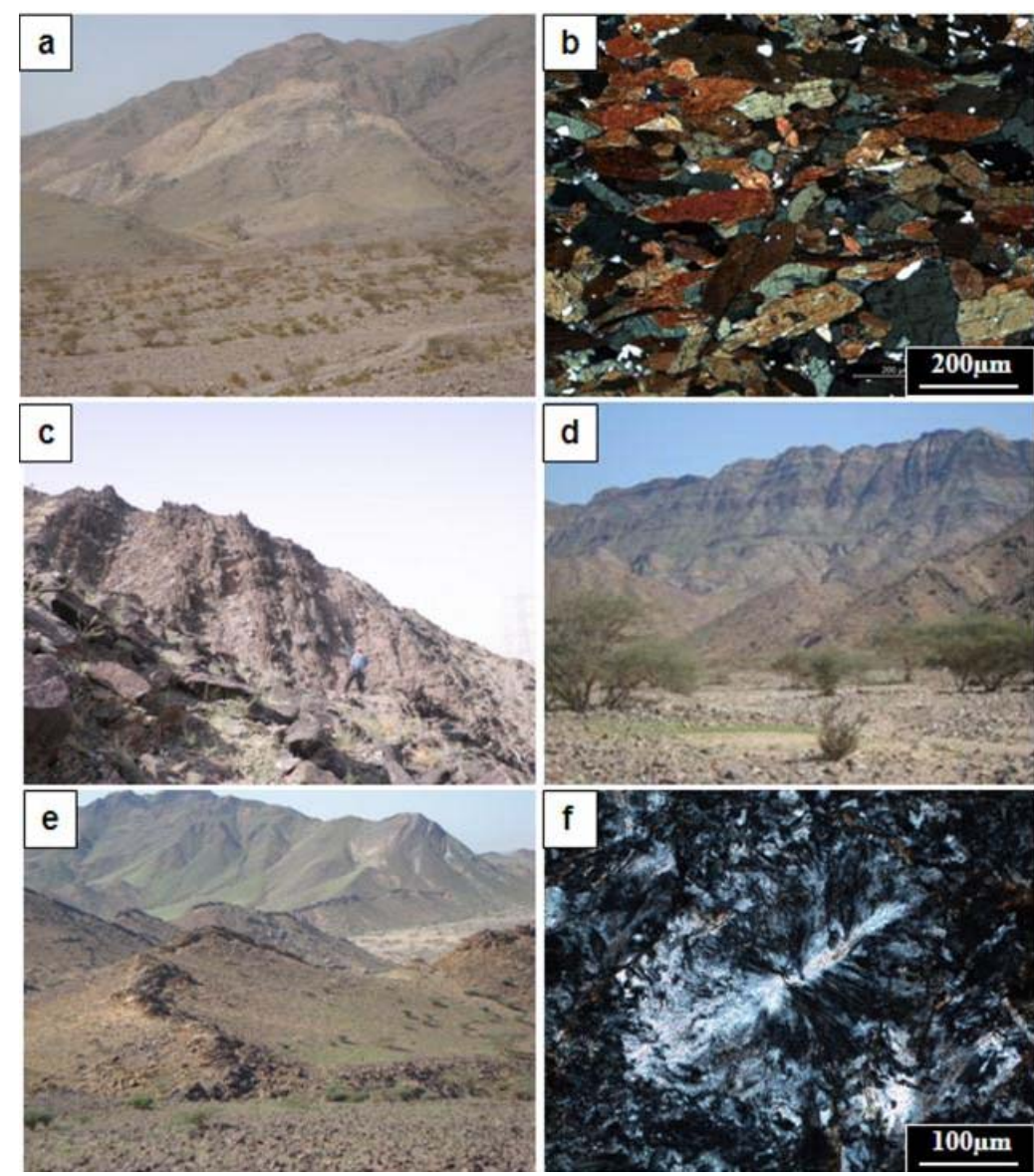

Figure 6. (a) A wide angle view showing the contact between amphibolites and Fatima, Jabal Daf, Looking WSW; (b) Preferably oriented hornblende, plagioclase and quartz crystals in amphibolite. C.N.; (c) Foliations, striking NE-SW and steeply dipping SE directions. Main Wadi Fatima. Looking SW; (d) Remarkable unconformity surface between Fatima Group and the older granites. Wadi Hashasha. Looking ESE; (e) ENE-WSW oriented mafic dykes traversing the older granites covering the eastern flank of Wadi Al-Shuba. Looking ESE. Note the dykes are not extended into the Fatima Group; (f) Microphotograph showing rhyolite with characteristic spheriolitic texture in rhyolite. C.N.

phenocrysts of white feldspar reaching up to $3 \mathrm{~mm}$ in length.

\subsubsection{Gabbros}

The gabbros are exposed in the form of two main masses to the north of Jabal Abu Ghurrah, in addition to other small exposures to the north of Jabal AlTwalat and unmappable masses along the flanks of Wadi Daf. The gabbros are intruded by the older granites. They are dark grey in color, coarse grained and consisting mainly of amphibole (mainly hornblende), pyroxene (augite) and plagioclase feldspar.

\subsubsection{Diorites}

The diorites cover vast domains along the flanks of Wadi Al Matahah and Wadi Al Muharrag. They are grey to dark grey, medium to coarse grained, nondeformed and intensively jointed. Petrographically, they are composed of plagioclase feldspar (andesine), hornblende and biotite, together with negligible amount of pyroxene. Zircon, apatite, sphene and opaques are accessories.

\subsubsection{Older granites}

The older granites occupy enormous sector in the mapped area and show unconformable contact with the overlying Fatima Group (Figure 6(d)). They are $773 \pm 16$ Ma old (Rb/Sr whole rock age; [11], and include xenolithic fragments and roofpendants of amphibolites and gabbros. Sometimes, the xenoliths are clustered in certain zones, oriented in the NE-SW direction. Additionally, they partially assimilate the andesites and gabbros. Such assimilation process led to the formation of a transition zone between the older granites and the intruded country rocks, ranging in composition from granodiorite to quartz diorite. Occasionally, the intrusive contact between the older granites and the juxtaposing rocks, particularly the amphibolites, is very difficult to be distinguished due to the effect of the later deformation and intensive shearing. Petrographically, the older granites consist mainly of quartz, 
plagioclase, biotite, orthoclase and hornblende, with secondary chlorite, calcite, and epidote and accessory titanite, apatite and opaques.

\subsubsection{Dykes}

The older granites, as well as the amphibolites, schists, andesites, and gabbros, are cut by confluence of dykes, oriented chiefly in the ENE-WSW direction (Figure 6(e)). These dyke swarms are not extended into the Fatima Group. Some dykes are composite in nature. In addition to the prominent trend of dykes additional unmappable N-S and E-W trends are also observed in the present study area. The ENE-WSW dykes vary from few meters to more than $1 \mathrm{~km}$ in length, and from a few centimeters to more than 20 meters in width. They range from basaltic andesites and andesites to rhyolites (Figure 6(f)) in composition. In most cases, the dykes being more resistant to weathering compared to the country rocks, forming well developed ridges stand out in relief. On both sides of any ridge, remarkable subhorizontal slickenlines are intermittently recognized.

\subsubsection{Younger Granite}

The younger granite forms small unmappable exposures in the mapped area (Figure 7(a)). It is pink in color, medium to coarse grained and non-deformed. It sends offshoots into and encompasses roofpendants of the preFatima basement rocks. In domains covered by the older granites it is very difficult to differentiate between both types of granites. Besides, the age relation between the younger granite and the dykes throughout the mapped area is so tricky and it is not easy to decide whether the dykes are older or younger. Petrographically, the younger granite is composed of alkali feldspar (orthoclase), quartz, plagioclase and biotite as essential minerals, where as apatite and opaques are accessory minerals.
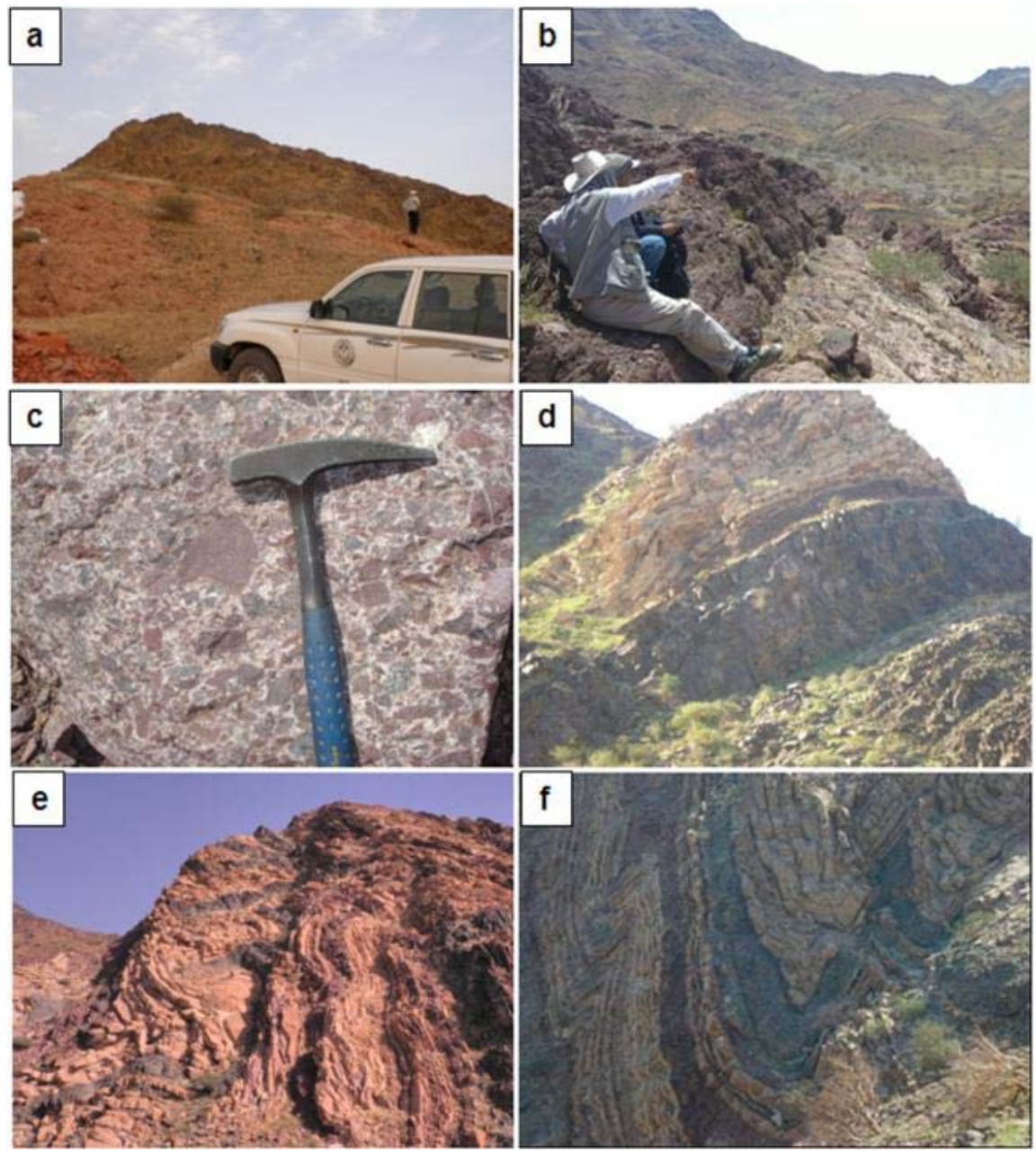

Figure 7. (a) A roofpendant of amphibolites resting over the younger granite. Wadi Al Kur. Looking NE; (b) Well-developed conglomeritic bed delineating the unconformity surface between Fatima Group and the underlying older basement. Wadi Hashash. Looking NW; (c) Polymictic basal conglomerate with randomly oriented fragments; (d) An andesite flow within the Fatima Group. Jabal Daf, Looking SE; (e), (f) Andesite bodies suffered the same history of deformation affected Fatima Group. Jabal Mukassar. 


\subsection{Fatima Group}

The Fatima Group (former "Série du Wadi Fati-ma”, [10]; Fatima Formation, [9] consists of unmetamorphosed to low grade greenschist facies metamorphosed sedimentary rocks overlie the basement, volcanics and related volcaniclastics, with an angular unconformity marked by the presence of polymictic conglomerate bed reaching up to several meters thick (Figures 7(b) and (c)). The basal conglomerate is overlain by a series of well-bedded sandy, silty and calcareous sediments with intercalated andesitic flows, in which three units are distinguished [8]: a) Lower clastic unit; a clastic sedimentary sequence of sandstones and siltstones with a predominantly greenish color, b) Middle carbonate unit; consisting of limestones, sandy limestones and marbles of a predominantly yellowish white color, and c) Upper clastic unit; consisting of a lower siltstone member and an upper pyroclastic member, with an overall reddish color. [13] gave the name "Fatima Group" and classified this group into three formations (from top to base); Daf Formation, Shubayrim Formation and Baqqar Formation. Within the sedimentary sequence of the Fatima Group several andesite bodies of various shapes and thicknesses do exist at different stratigraphic positions (Figures 7(d)-(f)). Some of these andesitic intercalations are evidently synsedimentary, that is, they were formed contemporaneously as volcanic flows with the enclosing sediments. The concrete field evidence indicating the synsedimentary volcanic flows include vesicular texture typical for lava flows and the regional extent of the andesitic intercalations. Other andesitic intercalations were obviously postdating sedimentation, because they extruded and invaded the Fatima sediments after their deposition in the form of sills and laccoliths, giving rise to chilled margins. Of particular interest to denote that whether the volcanic intercalations are flows or sills and laccoliths, they underwent the same history of deformation affected Fatima Group.

\subsubsection{Baqqar Formation}

The Baqqar Formation consists mainly of green siltstone, claystone, shale, and fineto coarse-grained arkosic and tuffaceous sandstone (Figure 8(a)). Cross stratification, current ripple marks and mud cracks characterize this formation and reveal a shallow water environment of deposition. The basal conglomerate bed that reaching up to $30 \mathrm{~m}$ thick is unconformably overlies the pre-Fatima basement, particularly the older granite. This bed contains sub-angular variably-sized fragments of quartz, andesites, granites and schists embedded within finegrained tuffaceous matrix. Locally, the conglomerate is interbedded with red siltstone. In some places, the basal conglomerate bed is completely absent and in such case a basal pyroclastic sequence (volcanic breccias, lapilli tuffs and agglomerates) overlies the underlying basement. The thickness of the volcanic pyroclastic unit may reach up to $250 \mathrm{~m}$ and sometimes being reduced to $1-2 \mathrm{~m}$ [8]. The upper contact of Baqqar Formation with Shubayrim Formation is frequently gradational and occasionally being sharp with andesites of Shubayrim Formation.

\subsubsection{Shubayrim Formation}

The lower part of Shubayrim Formation consists of sequence of alternating beds of clastic sedimentary rocks interbedded with thin layers of limestones, whereas the upper part consists of thick and massive beds of limestones interbedded with thin beds of clastic rocks (Figure 8(b)). The color of the clastic sedimentary rocks is greenish in the lower part of this formation and changes upward into bright red interbedding with whitish limestones. The sequence of Shubayrim Formation has lateral changes, but the general lithostratigraphic character is identical. A stromatolitic limestone bed characterizes the top of the limestone section (Figure 8(c)). A thick andesite flow occurs near the top of the Shubayrim Formation. This andesite flow is most distinctive marker bed in the sequence of Fatima Group. It divides the Shubayrim Formation into two units and separates the Shubayrim Formation from the Daf Formation. The bottom contact of the andesite flow with Shubayrim Formation and the top contact with the Daf Formation are sharp.

\subsubsection{Daf Formation}

Daf Formation consists of a Lower Siltstone Member and an Upper Pyroclastic Member [8], with an overall reddish color. The Lower Siltstone Member is intercalated with few andesite layers up to $5 \mathrm{~m}$ thick and manifested by a red, fine-grained, massive, medium to poorly bedded, and intensively jointed siltstone. Upsection, the siltstone grades into a poorly bedded, arkosic sandstone 2 $5 \mathrm{~m}$ thick. Medium-grained, red, arkosic sandstone and red lapilli tuff occurs as thin interstratifications within the Red Siltstone Member. The bedding surfaces often exhibit primary sedimentary structures, such as: ripple marks and mud cracks. The Upper Pyroclastic Member has its maximum thickness of $500 \mathrm{~m}$ at Jabal Daf, and is completely removed by erosion in some other places such as Jabal Abu Ghurrah. It is composed alternating layers of variable thicknesses of volcanic breccia, lapilli tuff, agglomerate and andesite flows. Layers of red siltstone, brown greywacke and red arkosic sandstone are intercalated within the Upper Pyroclastic Member.

\subsection{Shumaysi Formation}

The term Shumaysi Formation (former "Shu-maysi Series); [10] was introduced by [20]. This formation was described in some details by [7]. It is a sequence of red 

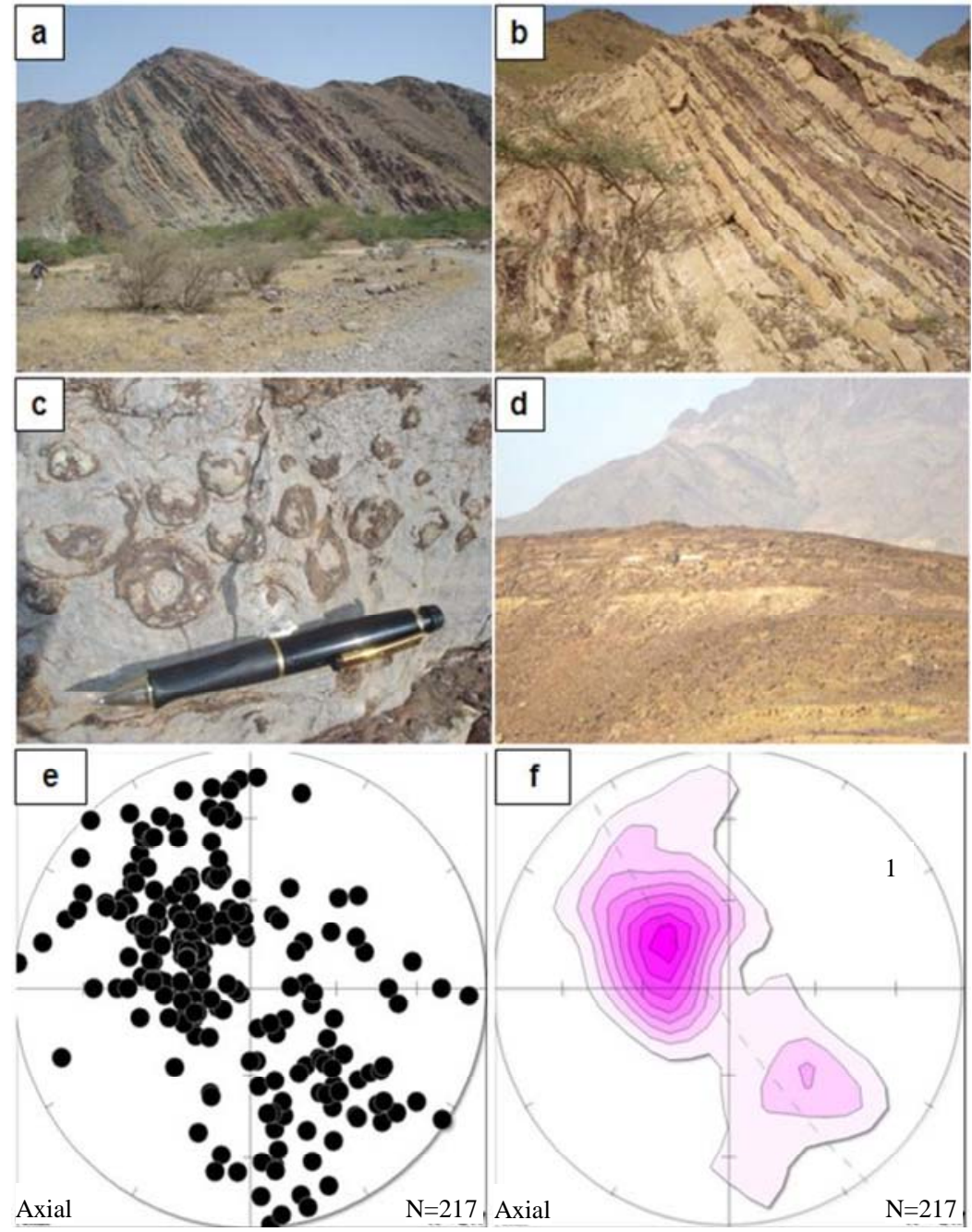

Figure 8. (a) An andesite sill extruded into Fatima Group. Jabal Abu Ghurrah; (b) A sequence of alternating beds of clastic sedimentary rocks interbedded with thin layers of limestones forming the lower part of Shubayrim Formation. Looking NE; (c) Silicified stromatolitic carbonate oncoids. Shubayrim Formation, Fatima Group; (d) A small exposure of Shumaysi Formation encountered in Wadi Al Kur. Notice Fatima Group of Jabal Mukassar in the background. Looking NE; (e), (f) Orientational data (lower hemisphere equal area projections) of the poles to 217 bedding planes measured throughout the entire Wadi Fatima area: (e) pole diagram and (f) its contour equivalents. Contours per unit area are observed to the right of the diagram.

clastic rocks of Oligocene age recognized in the area of Wadi Fatima and Wadi Shumaysi, and overlies nonconformably the crystalline basement rocks. The main sedimentary units of this formation include beds of sandstone, siltstone, shale, pebbly sandstone, chert, volcanic ash and oolitic hematite, overlain by a basalt flow of unknown thickness. In the mapped area, Shumaysi Formation is recorded as exposures of limited extent, surrounded by Quaternary fan deposits, in Wadi Al Kur (Figure 8(d)). These exposures are tilted towards the NE direction with an angle ranging between $15^{\circ}-35^{\circ}$.

\section{Structural Framework}

The various types of structures recorded in the study area comprise non-tectonic structures (primary structures) and tectonic structures (secondary structures); both of them are manifested by their characteristic structural features throughout the entire Wadi Fatima area.

\subsection{Non-Tectonic Structures}

In Wadi Fatima area, the non-tectonic structures are well recognized, being represented mainly by bedding and lamination, graded bedding, ripple marks, sole marking and load casts, as well as stromatolitic structures. In Fatima Group, bedding consists of thinly laminated beds, thin beds, medium beds and thick beds. It is often highlighted by spectacular variations in colors and the differential weathering and erosion between adjacent beds. 
The bedding planes are generally striking NE-SW and dipping toward NW and SE. Some 217 readings of the attitudes of bedding are collected all over the study area, and plotted on Schmidt lower hemisphere equal area stereonet (Figures 8(e) and (f)). Graded bedding and ripple marks (symmetric and asymmetric) are well represented in some exposures of the lower Fatima Group (Baqqar Formation). Sole markings and load casts are also intermittently encountered in the lower unit of Fatima Group.

Stromatolites occur at several stratigraphic levels. [21] determined three levels and described three forms of stromatolites: lenticular stromatolites, cupuliform stromatolites corresponding to the form collenia, and stromatolites with a central column of quartz. On the other hand, [8] referred to five stratigraphic levels for existence of the stromatolites within Fatima Group. One of them has a consistent stratigraphic position and regional extent; it is represented by stromatolitic limestone that is existing beneath the andesitic layer within Shubayrim Formation. The stromatolites of the other stratigraphic levels have local importance; because they disappear laterally after short distances. However, the encountered stromatolites, together with other primary sedimentary struc- tures, are used in the determination of facing (younging direction or right way attitudes) of bedding planes during geologic traverses carried out all the way through the Wadi Fatima area. Understanding of facing played a significant role in unraveling the complicated structures of the area.

\subsection{Tectonic Structures}

In the mapped area, tectonic structures are manifested by folds, foliations, lineations, shear zones and faults.

\subsubsection{Folds}

Folds are the most prominent and outstanding structural features throughout the entire Wadi Fatima area, and are recorded at various scales. Field observations, superposed (overprinting) relations and collected structural measurements revealed that the area has underwent a deformational history involving, at least, four phases of folding (F1, F2, F3 and F4). F1 folding phase is frequently accompanied with an oldest outstanding dextral shearing phase affected the main Wadi Fatima during the Neoproterozoic (Figure 9(a)). These shear zonerelated folds are represented by attenuated tight isoclinal folds,
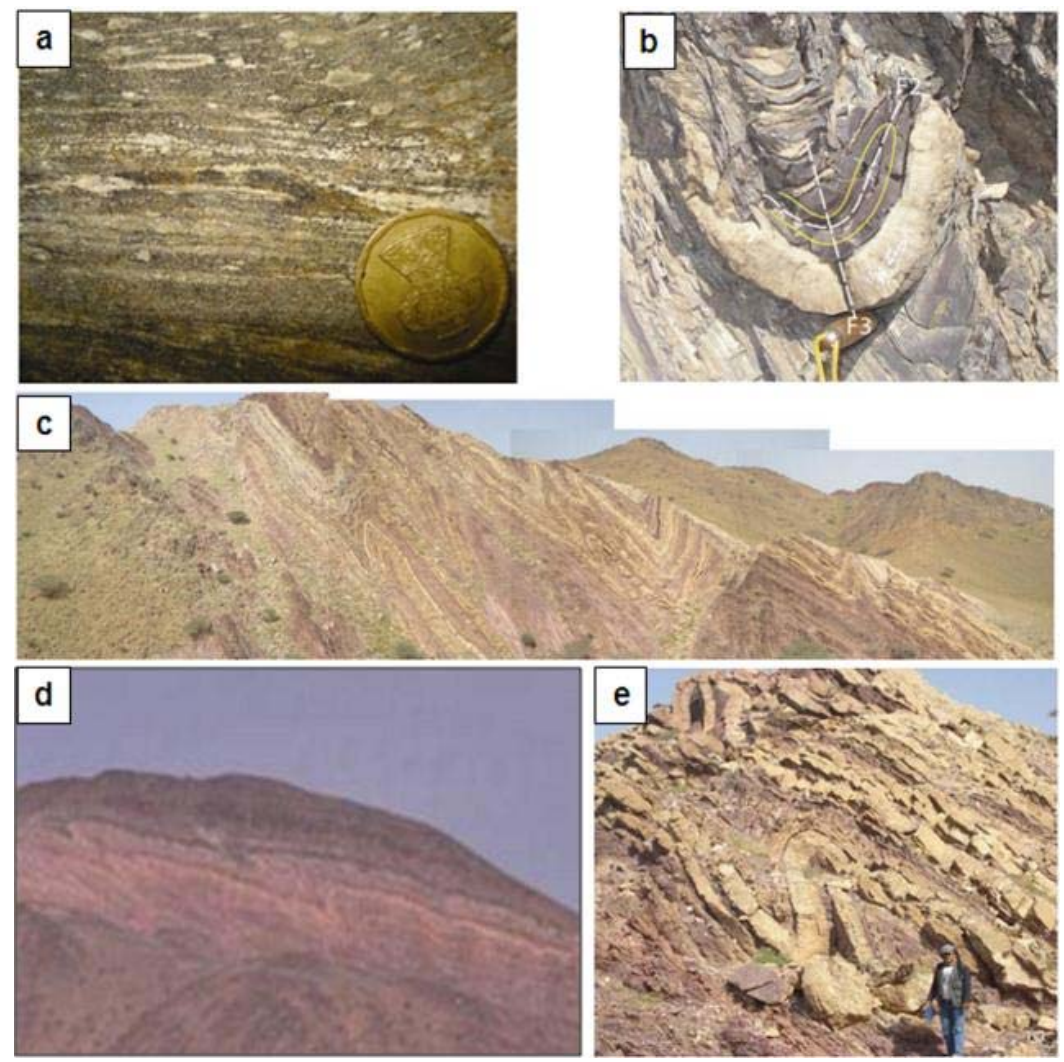

Figure 9. (a) F1 tight isoclinal shear zone-related folds in the amphibolites. Main Wadi Fatima; (b) F2 tight iso-clinal folding refolded by F3 open folding within Shubayrim Formation. Jabal Mukassar, Looking NE; (c) Panoramic view showing thrust-related folds. Southwest of Wadi Daf; (d) Well-developed thrust-related folding in Jabal Mukassar; (e) Photograph showing overturning folding preceding thrusting. 
sheared-out hinges and tight fold closures. These structures are encountered in the pre-Fatima amphibolites and schists, as well as marble blocks, and are not recorded in Fatima Group at all. They show intimate relation with shear fabrics, NE-SW foliation planes and subhorizontal stretched and mineral lineations. F1 shear zone-related folds often show variable orientations due to the effect of subsequent deformations. On the other hand, the latest three phases of folding (F2, F3 and F4) are recognized in Fatima Group and not detected in the underlying basement complex, and this strange circumstances will be the matter of discussion later. F2 folding phase is manifested by tight isoclinal folds with variable orientations (Figure 9(b)). F3 folding phase seems to be geometrically and kinematically related to the main thrusting phase affected Fatima Group (Figures 9(c)-(e)); the thrusting phase played a noteworthy role in the structural shaping of the whole Wadi Fatima District. F3 thrust-related folds are regularly overturned and/or inclined, with mild southeastern limbs and steep northwestern overturned limbs; the direction of overturning (folding vergence) varies from NW to NNW, and occasionally to N. Their geometry in profile is concentric and ranging from angular to curvilinear, and their axes are gently plunging $\mathrm{NE}$ to ENE (Figure 10(a)). It is worthy to mention here that, because of large differential flow associated with thrusting in Wadi Fatima area, some parts of the fold axial regions may advance relative to other parts, forming sheath or eye folds (Figure 10(b)). F4 folding phase led to the formation of open folds, striking NW-SE to NNW-SSE and moderately to steeply plunging towards the SE to SSE direction.
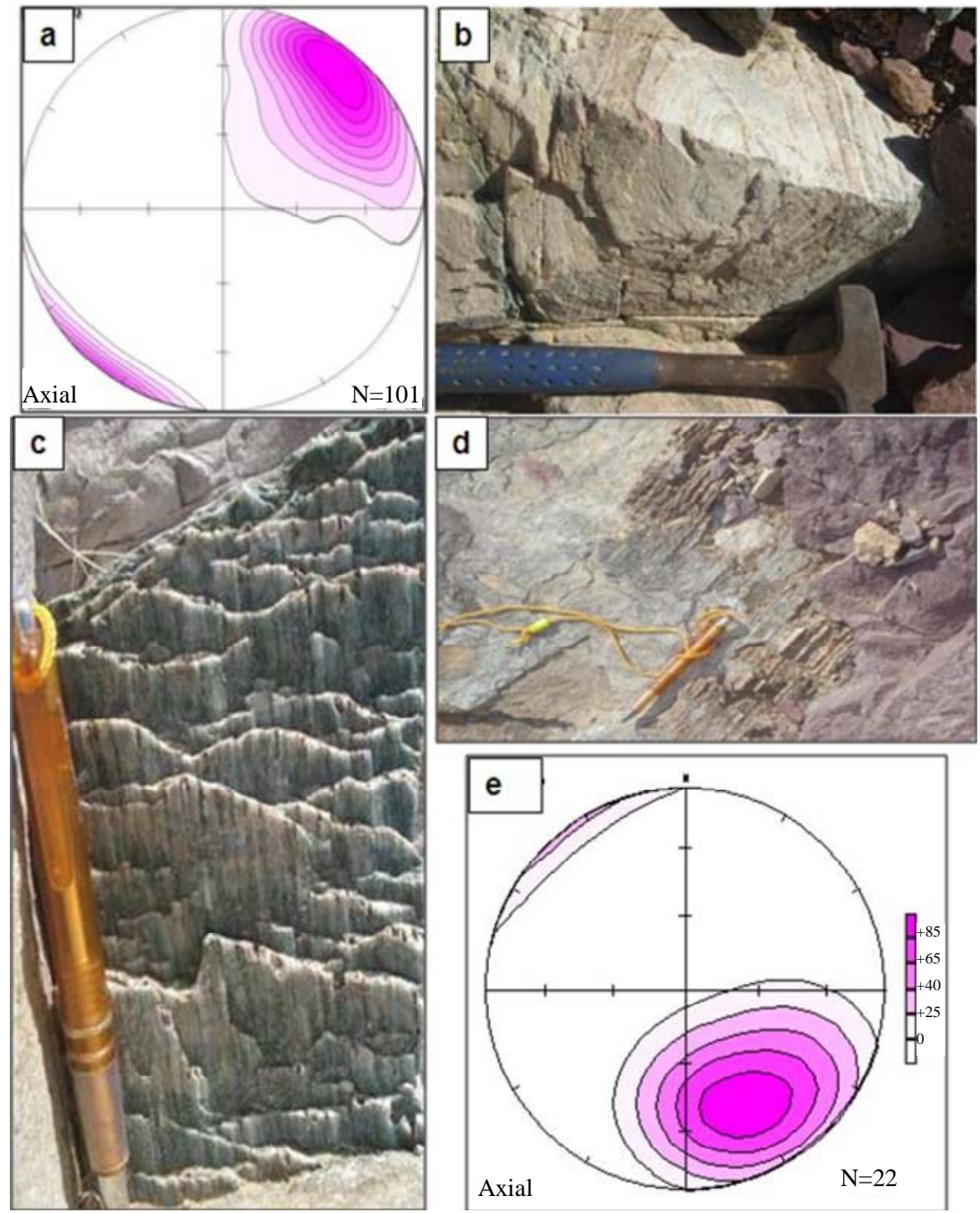

Figure 10. (a) Orientational data (lower hemisphere equal area projection) of 101 small F3 fold hinges measured throughout the intact Wadi Fatima area. Contours per unit area are observed to the right of the diagram; (b) Well developed sheath fold in Fat-ima Group; (c), (d) Slickenlines formed due to slipping along bedding planes during thrusting propagation in Wadi Hashasha, and Jabal Shubayrim; (e) Orientational data (lower hemisphere equal area projection) of 22 slickenlines measured throughout the study area. 
Several lines of evidence revealed that the majority of the eye-catching folds in the entire Wadi Fatima District are formed by flexural slip mechanism. Flexural slip folding accommodates buckling by layer parallel slip along contacts between layers. The Slipping along the bedding planes (layer-parallel slipping) during folding led to the formation of parallel grooves or bedding plane slickenline striae perpendicular to folding axis. Such slickenline striae are prominent in folded Fatima Group, indicating that folding took place throughout flexuralslip mechanism during deformation.

\subsubsection{Foliations}

Foliations are observed in pre-Fatima basement, particularly in schists and amphibolites that are cropping out along the southeastern flank of the main Wadi Fatima. Foliation planes strike NE-SW and dip at moderate to steep angles towards the NW and SE directions (see Figure 6(c)). The deformational phase responsible for the formation of foliation in study area is the oldest shearing phase affected Wadi Fatima District pre-dating the deposition of Fatima Group. Based on the classification proposed by $[22,23]$, it is clear that foliations in schists and amphibolites of Wadi Fatima area are continuous foliations; since they are consisting of non-layered homogeneous distribution of platy mineral grains with a preferred orientation, in addition that the grains that define the foliations could be observed by naked eye.

\subsubsection{Lineations}

Lineations recorded in the study area are represented by grooves, fibers and striations formed due to slipping along bedding planes during thrusting propagation (Figures 10(c) and (d)). They plunge at various angles towards NW, NNW to N, as well as towards SE, SSE and $\mathrm{S}$ directions (Figure 10(e)).

\subsubsection{Faults and Shear Zones}

[8] classified faults crossing Wadi Fatima district into three groups. The first group is the faults that define the Wadi Fatima graben. It has NE-SW trend and represents the oldest faults recorded throughout the area. The second group of faults includes strikeslip or oblique slip faults produced by shearing and possessing NNW-SSE trend. According to these authors, the second group faults is considered to divide the entire northwestern block of Wadi Fatima into horsts (Jabal Abu Bakr, Jabal Shubayrim, Jabal Daf, Jabal Mukassar and Jabal Abu Ghurrah) and grabens such as the block covered by Wadi Faj and that covered by Wadi Al Kur. The third group of faults exhibits NNE-SSW trend and are formed conjugated to the second group. In the present work, two main sets of faults are recognized in the mapped area; NE-SW and NW-SE (to NNW-SSE). The NE-SW trending faults are manifested by Wadi Fatima Shear Zone (WFSZ). WFSZ shows dextral sense of shear (Figures 11(a)-(d)) concurrent with other NE-oriented major shear zones in the ANS, such as Ad-Damm Shear Zone [16,24] and QenaSafaja Shear Zone [25].

Parallel to WFSZ are some less extended faults exhibiting oblique sense of movement. The most important of these faults is Wadi Salah-Wadi Hashasha Fault. This fault intensively cataclased the pre-Fatima older granites and resulted in the formation of oblique slickenlines in quartz vein and mafic dyke swarms invading and extruding the basement complex, as well as in older granites. The NW-SE (to NNW-SSE) faults seem to be genetically and kinematically related the Red Sea rifting. They are considered to represent listric normal faults crossing wadies that are running normal to the main Wadi Fatima (Figures 12(a)-(d)). The most important of these faults are Wadi Faj-, Wadi Al Kur-, Wadi Daf-, and Wadi Al She'ba-Faults. Wadi Faj Fault separates Jabal Abu Ghurrah and Jabal Sidir in one side from Jabal Mukassar and Jabal Al Twalat in the other side. Wadi Al Kur Fault splits Jabal Mukassar and Jabal Al Twalat from Jabal Daf. Wadi Daf fault divides Jabal Daf from Jabal Abu Bakr and Jabal Shubayrim. Wadi Al She'ba Fault segregates the granitic and andesitic rocks recorded along the western flank of Wadi Al She'ba from Jabal Shilwa situated just to the east of the mapped area. Evidence indicating that previously mentioned faults are listric normal faults include: 1) tilting of the stratigraphic succession of Fatima Group towards the NE or ENE direction, 2) emerging of isolated exposures of the Oligocene sediments of Al-Shumaysi Formation in both Wadi Faj and Wadi Daf, 3) direct juxtaposition of pre-Fatima basement (mainly older granites) that are frequently exposed along the NE or ENE flanks of Wadi Faj, Wadi Al Kur, Wadi

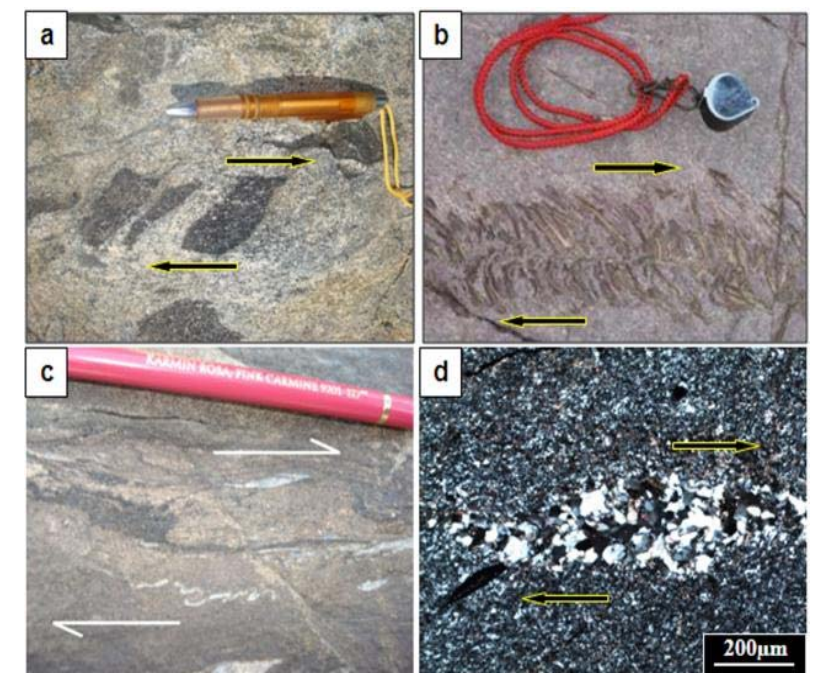

Figure 11. (a)-(d) Kinematic indicators revealing dextral shearing along Wadi Fatima Shear Zone. 


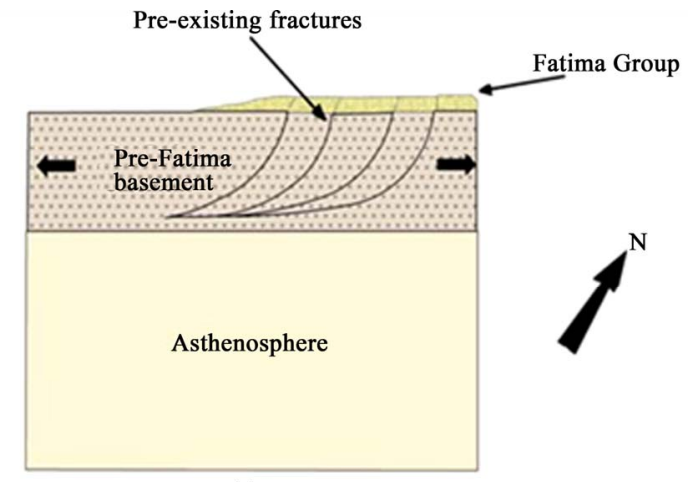

(a)

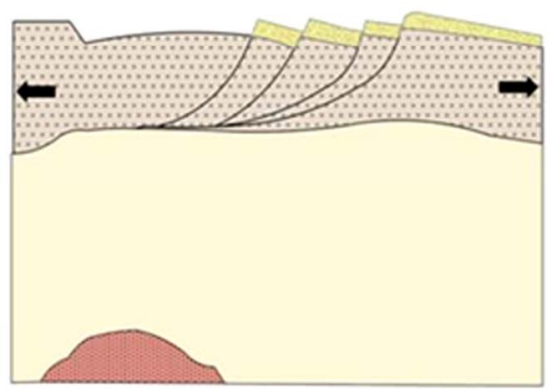

(b)

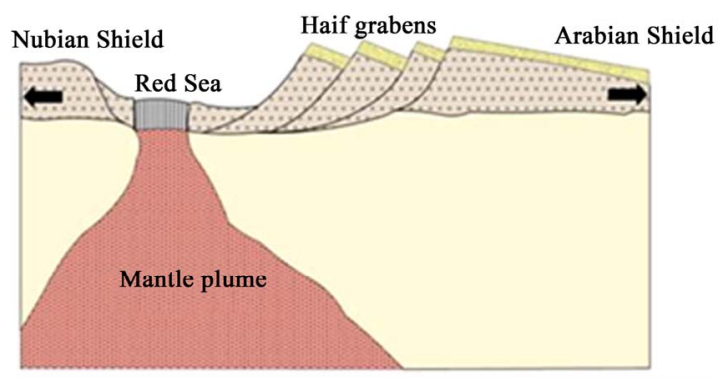

(c)

Figure 12. Proposed schematic diagrams showing rifting and tilting of Fatima Group along Red Sea-Related listric normal faults.

Daf and Wadi Al She'ba with Fatima Group that are encountered along SW or WSW flanks of these wadies. The foregoing evidence may indicate also that the whole Wadi Fatima district is an intra-rift block which is itself comprising several half grabens or tilted fault sub-blocks; referring here as Jabal Abu Ghurrah, Jabal Mukassar, Jabal Daf and Jabal Shubayrim half grabens.

\section{Thrusting and Thrust-Related Structures}

Fold-and-Thrust (FAT) belts occur worldwide in a variety of tectonic settings basically, anywhere that a layer of the upper crust undergoes significant horizontal shortening under low-grade or sub metamorphic conditions. Among these tectonic settings are [26]: foreland of an Andeantype convergent margin, accretionary prisms bordering a trench, foreland sides of a collisional orogenic belt, inverted rift basins, seaward edge of passive-margin sedi- mentary basins and restraining bends along large continental strike-slip fault. Field relations and outcrop investigations revealed that Wadi Fatima FAT belt could be affiliated to the third tectonic setting, which is foreland sides of a collisional orogenic belt. As in many areas in ANS, thrusting and thrust-related structures were formed by the effect of shortening (Figure 13) accompanying the continental collision between East and West Gondwana [1]. Thrusts propagated sequentially according to the "footwall-nucleatingfootwall-vergentrule" in sequence manner. Out-of-sequence thrusting, pop-up structures (Figure 14(a)) and triangular zones are infrequently recognized. The attitudes of thrusts throughout the entire Wadi Fatima district are nearly identical; striking NE-SW to ENE-WSW and dipping SE to SSE. On outcrop scale, thrusts frequently show flat-ramp-flat geometry. Because of their piggy-back imbrication, the SE to SSE-dipping thrust ramps regularly show sequential decrease in dip or inclination into their transport direction. Furthermore, thrusts occasionally give an impression that they were formed during two main sub-stages; an older sub-stage during which bedding sub-parallel thrusts were formed, and a younger sub-stage which generated younger ramps oblique to bedding. Close to the pre-Fatima basement, thrusts seem to develop under ductile to brittle conditions and those located away from the contact were deformed under brittle conditions, and thrust sheets themselves may be transported by brittle translation. The geometry of interacting out-crop and map-scale folds and thrusts, patterns of thrust displacement variations and indications for hinge migration during fold growth, strongly suggest that folding and thrusting in Wadi Fatima FAT belt are geometrically and kinematically linked and that thrusting initiated as a consequence of folding (fold-first kinematics) (Figure 14(b)). This indicates that thrust-related folds in the study area could be joined to break-thrust folds. The existence of thrust faults in Wadi Fatima region was accommodate the shortening and vergence processes when inability of the folding alone to accommodate contraction or shortening. In some outcrops, particularly in Jabal Daf, arrays of thrust horses bounded by floor thrusts (sole thrusts) at the base and by roof thrusts at the top are recognized at different scales from handspecimen scale to exposure scale, forming well developed imbrications and thrust duplexes (Figures 14(c)-(f)). [19] came to the conclusion that Wadi Fatima thrust duplexes are passive-roofed duplexes. In such duplexes, the roof thrust slips only when the floor thrust ruptures.

\section{Tectonic Evolution and Conclusions}

\subsection{Wadi Fatima Foreland FAT Belt}

Fold-and-Thrust (FAT) belts comprise various kinds, including: foreland FAT belts and crystalline thrusts, accretionary prisms and toe thrust belts, each of which dis- 


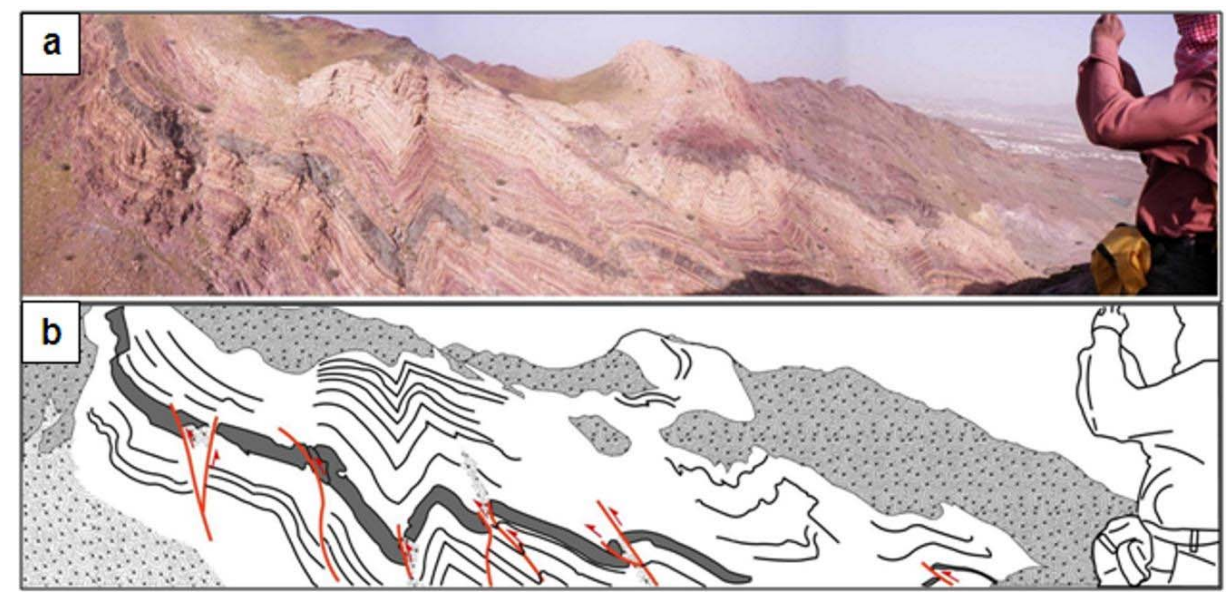

Figure 13. Panoramic view and a simplified sketch showing thrusting and thrust-related structures in Shubayrim Formation of Fatima Group. Jabal Shubayrim. Looking E.

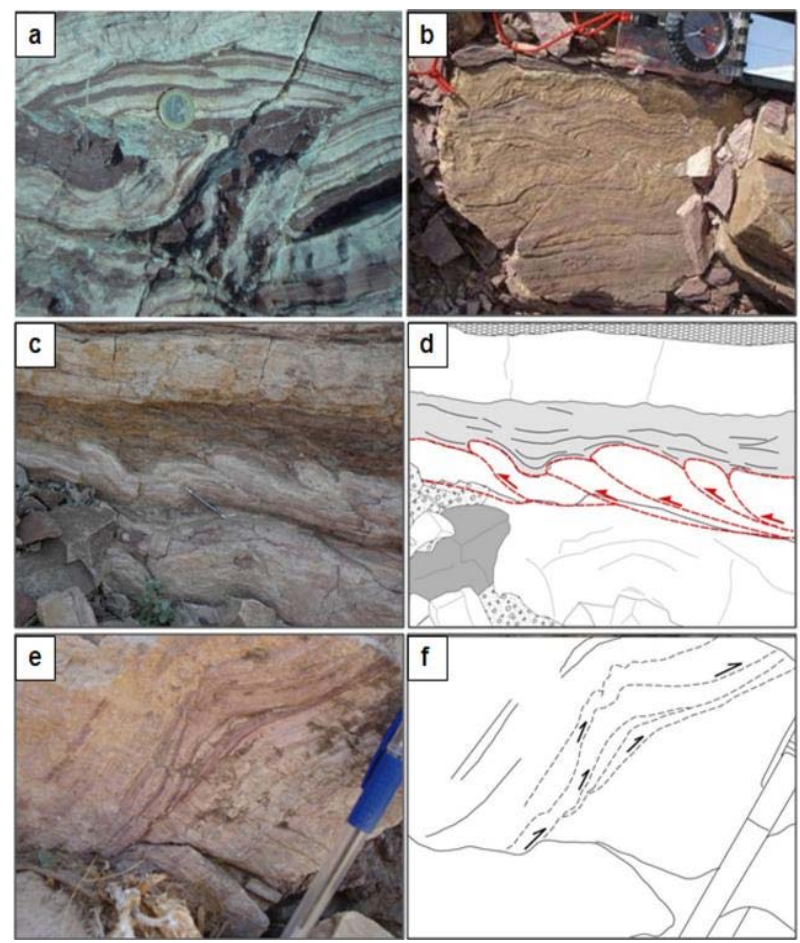

Figure 14. (a) Well developed pop-up structure in Daf Formation of Fatima Group; (b) field photograph at-testing fold-first kinematics (i.e. thrusting was formed a consequence of folding); (c)-(f) Thrust-duplexes in Shubayrim Formation of Fatima Group and illustrated sketches.

plays distinctive characteristic features [27]. The foreland FAT belts are 10 to $1000 \mathrm{~km}$ wide and constitute the external zones of orogens. They involve an unmetamorphosed or low-grade metamorphic sedimentary cover, whose thickness decreases towards the foreland (interior of a continent), deposited over a metamorphic/igneous basement, whose top usually dips towards the hinterland (ancient sea), that constitute the passive continental margin. They usually show a wedge geometry in cross-sec- tional view and this shape is maintained throughout the deformational history of the belt. Accretionary prisms (e.g. $[28,29]$ are the main locus of deformation in subduction zones, where the rock assemblages are mechanically scraped off the downgoing oceanic slab and accreted to the seaward edge of the upper advancing plate forming thrust sheets. Unlike other FAT belts, toe thrust belts do not require lithospheric shortening, their deformation and transport are achieved entirely by gravity. They are generally detached on salt or overpressured shales and are, therefore, unrelated to the basement. Wadi Fatima FAT belt is a piggy-back basin, showing most of the essential characteristic features of foreland FAT belts. It is relatively wide belt, involving unmetamorphosed to slightly metamorphosed sedimentary sequence decreasing in thickness in the direction of the foreland, and deposited over the pre-Fatima metamorphic/igneous basement rocks including amphibolites, schists with occasional unmappable blocks of marbles, hornblendite and metagabbros, and older and younger granites. In this belt, the styles of deformation encompass flexural-slip folding forming mesoscopicand map-scales NE to ENE plunging overturned antiforms and synforms, and a thrust duplex system bounded by floor thrust and sole thrust (basal detachment) dipping gently towards the hinterland and rises stratigraphically upwards towards the foreland. The style of deformation of Wadi Fatima FAT belt is affiliated in the present study to thin-skinned deformation (Figure 15), for the reason that thrusting involves only the sedimentary sequence of Fatima Group, whereas the underlying basement remains unaffected by thrusting with the exception of limited number of low angle reverse faults that encountered in the older granite exposed along the flanks of Wadi Hashasha. Close to the basement, thrusts appear to develop under ductile to brittle conditions and those located up section were formed under brittle conditions, and thrust sheets may be trans- 

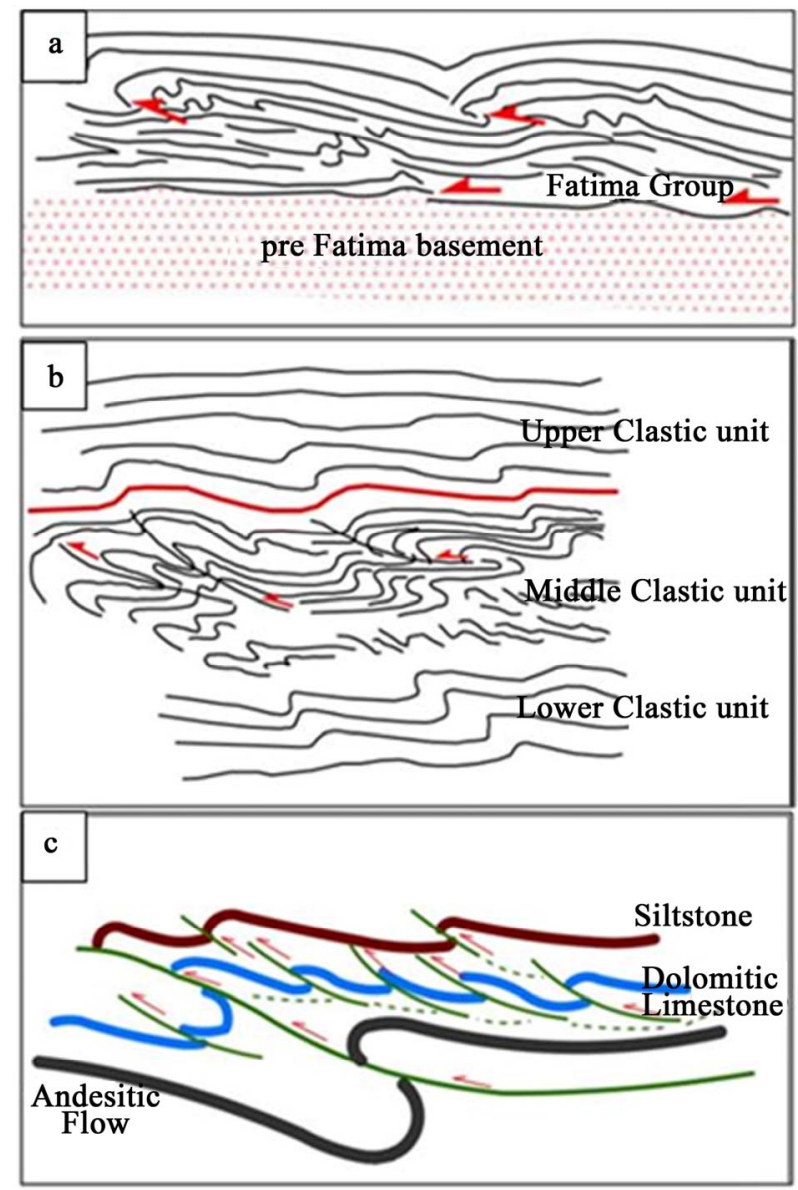

Figure 15. Sketches showing thin-skinned deformation in Wadi Fatima area; where thrusting and thrust-related structures are confined to the sedimentary cover (Fatima Group) and not extended into the underlying basement.

ported by brittle translation. The thinskinned structural style contrasts with the thick-skinned style of basement-involved belts [30], in which both the sedimentary cover and the underlying basement are deformed due to shortening or contraction and affected by the same system of thrusting. In the thick-skinned belts, the basement is incorporated into the thrust sheets due to: a) steep faults that penetrate the basement and create basement uplifts; and/or b) reactivated inherited basement fabrics that control the subsequent thrust architectures such as inverted half-grabens.

As in other FAT belts and in many deformed sedimentary terranes, different fold and thrust styles develop in the juxtaposing layers in Fatima FAT belt. This variation is influenced by a number of factors, the most important of them are variation in lithology and thickness. It is well known that folds tend to develop in lithologies that are more susceptible to ductile deformation which are increasingly common as pressure and, particularly, temperature increase with depth, whereas faults and thrusts may form in lithologies more borne to brittle de- formation which dominate the upper crust [31]. In Wadi Fatima FAT belt, although both folding and thrusting are well recognized in the middle carbonate unit (Shubayrim Formation) compared to the lower clastic unit (Baqqar Formation) and the upper clastic unit (Daf Formation), folding appears to develop more in clay-rich sediments of the lower unit and thrusting emerges in middle carbonate-rich unit, as well as in andesitic flows. Variable thickness look like to play a role in variation of fold and thrust styles in adjoining layers, where folding appears easily in thinner layers, and on the other hand thrusting becomes visible in thicker layers.

\subsection{A Proposed Tectonic Model}

The tectonic evolution of Wadi Fatima FAT belt, westcentral part of the Arabian Shield, Saudi Arabia, could be described by the following stages (Figure 16):

1) The pre-Fatima amphibolites and schists, together with the enclosing marble, pyroxenites and meta-gabbro blocks was affected by a dextral shearing during the early convergence and amalgamation between East and West Gondwana (Stage I).

2) Emplacement of the older granites during a period of crustal cessation and relaxation (Stage II). The existence of minor NE-SW trending shear zones with remarkable dextral shear sense indicators within the older granites revealed that the previously mentioned shearing stage is most probably prolonged and at the same time being attenuated in close proximity to its ending.

3) The pre-Fatima older granites, as well as the amphibolites and schists, was subjected to a NNW-SSE extensional stage resulted in the development of ENEWSW open fractures (Stage III).

4) Ongoing of the extension was accompanied by the extrusion of NNW-SSE dyke swarms (Stage IV); some of these dykes are composite and others are openly folded. Slickenlines observed along the dykes indicate diagonal-slip movement.

5) Emplacement of the younger granites during another period of crustal relaxation (Stage V). This type of granites is not affected by shearing at all. It sends offshoots into, and containing xenoliths of, the pre-Fatima amphibolites, schists and older granites.

6) Deposition of Fatima Group over an ancient peneplain, marked by poorly sorted polymictic basal conglomerates containing fragments and pebbles of the pre-Fatima basement (Stage VI). The unconformity is proved by the following field relations: a) the presence of the basal conglomerate bed without any preferred orientation of its fragments, b) the presence of older and younger granitic fragments within the basal conglomerate bed, c) intensive weathering and peneplaination of the pre-Fatima basement, particularly the older granites, close to the contact with the overlying Fatima Group, and 
d) absence of slicken line striae or striations and stretched lineations within and nearby the basement Fatima contact. Fatima Group was considered to represent the post-amalgamation marine basins [4] and posses a depositional age ranging between 688 - $680 \mathrm{Ma}[11,12,15]$. The to a predominant granitic source area, the presence of reef-building stromatolites with Middle and Upper Fatima supports the view of a marine environment, at least

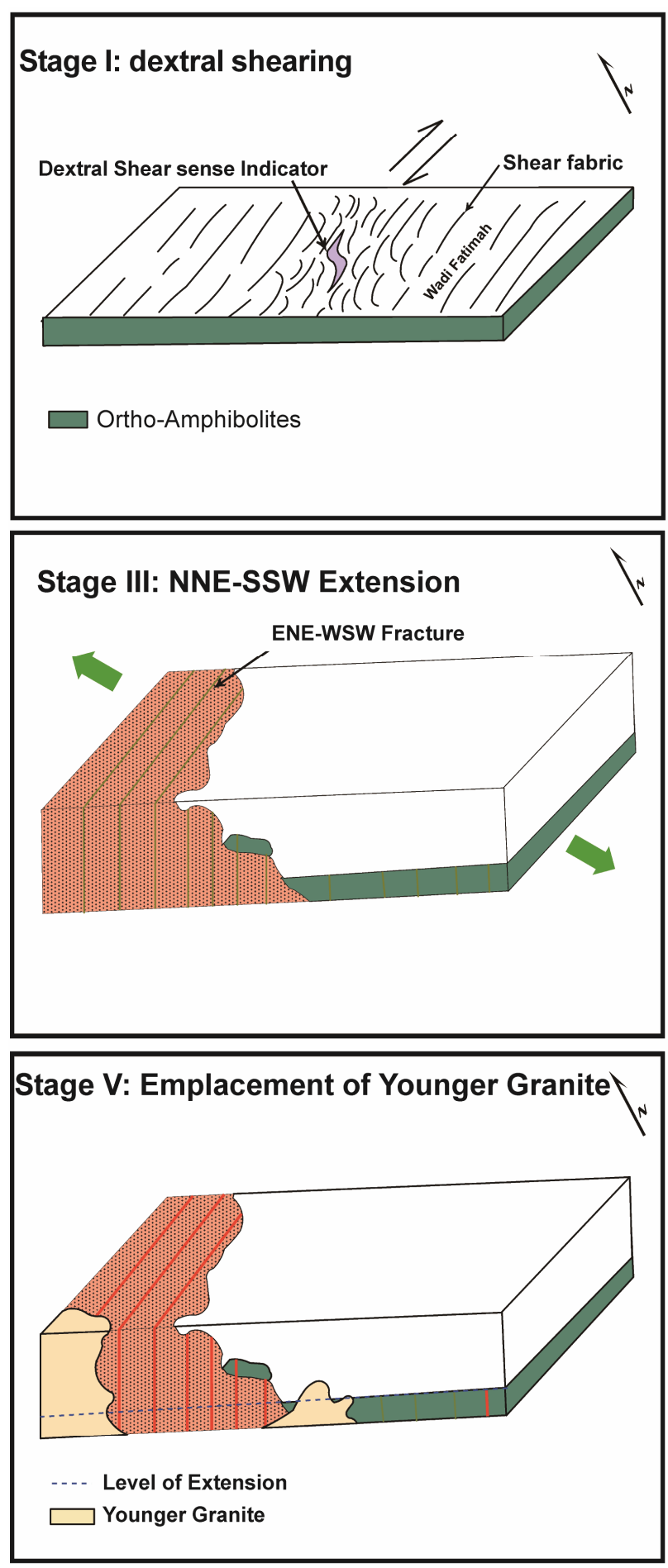

for that part of the Fatima Sequence, the presence of ripple marks and burrow casts suggests a littoral environment, whereas mud cracks support closeness to the shoreline, horizontal and vertical changes in thickness and lithologies are explained by minor oscillations affected the shallow water environment. From the above-listed lithologic and stratigraphic features [8] came to the conclusion that the Fatima Formation (currently Fatima Group; [13]

\section{Stage II: Emplacement of older granite}

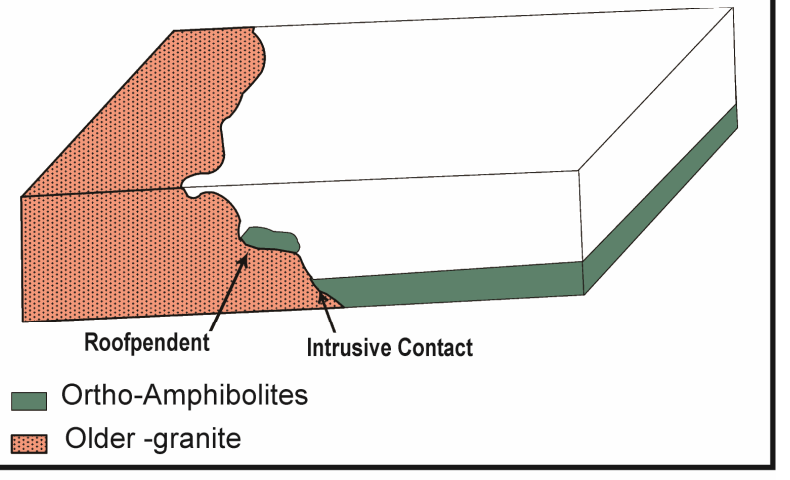

\section{Stage IV: Extrusion of Dykes}

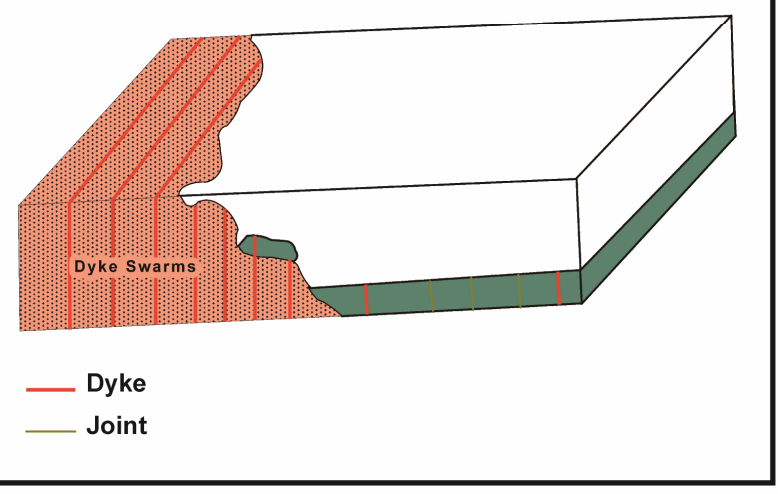

Stage VI: Layer-parallel shortening

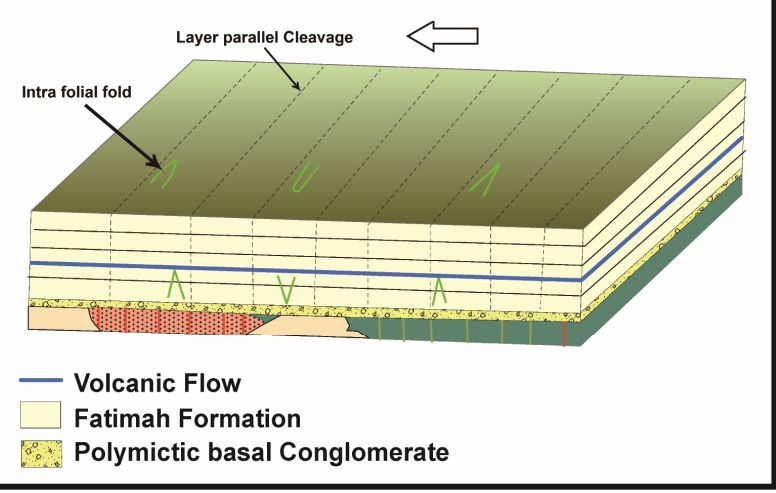



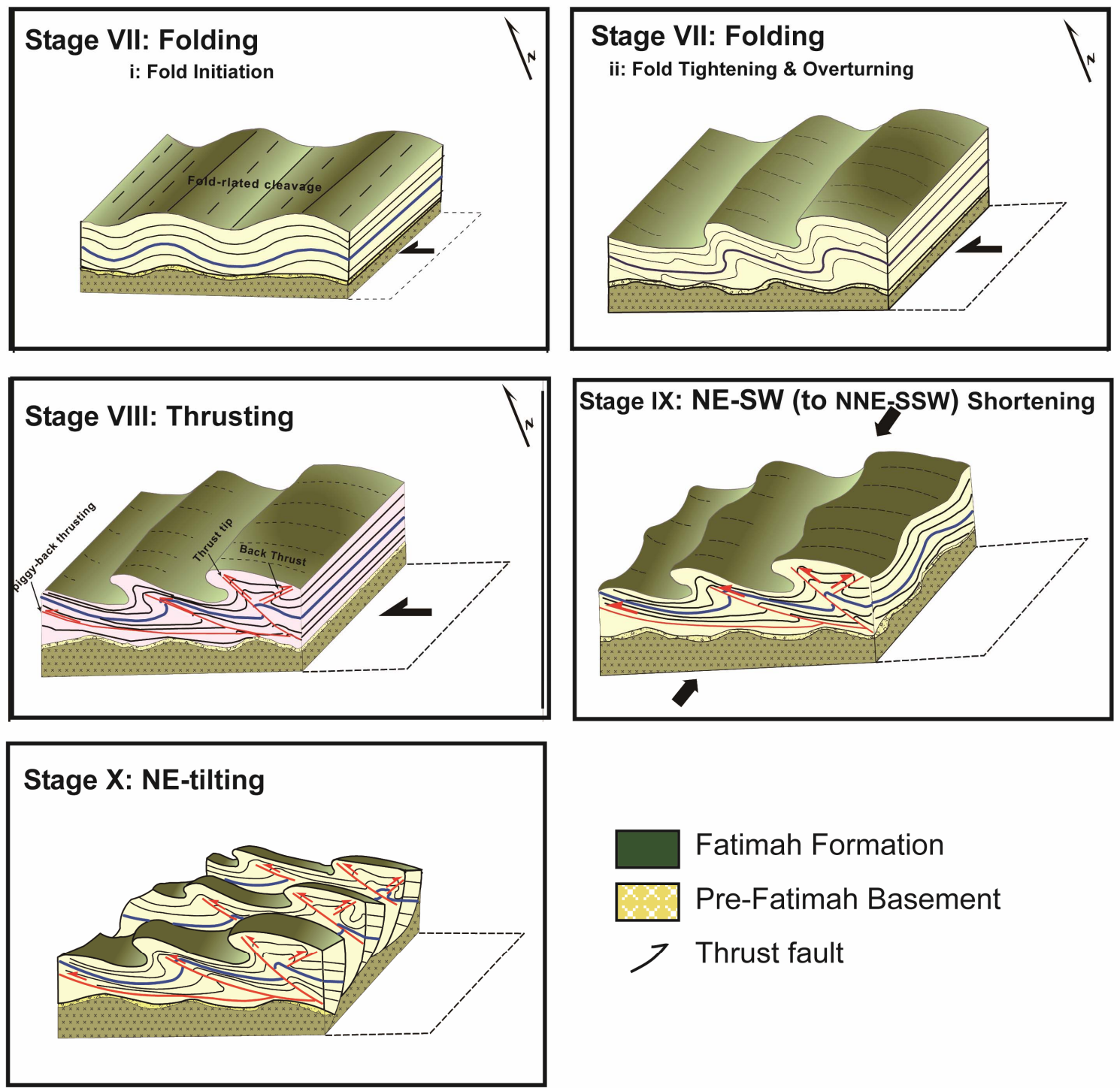

Figure 16. 3-D cartoon illustrating the evolution of Wadi Fatima FAT belt. Stage I: Dextral shearing during the early convergence and amalgamation between East and West Gondwana. Stage II: Emplacement of the older granite during a period of crustal cessation and relaxation. Stage III: NNW-SSE extension. Stage IV: Extrusion of dyke swarms. Stage V: Emplacement of younger granite. Stage VI: Deposition of Fatima Group over an ancient peneplain and layer parallel shortening. Stage VII: Fold initiation, fold tightening and overturning. Stage VIII: Thrusting. Stage IX: NE-SW (to NNE-SSW) shortening. Stage $X$ : NE tilting accompanied with Red Sea rifting.

was deposited in a shallow water marine environment, corresponding to a slowly subsiding basin of geosynclinal character.

7) After its deposition, Fatima Group (with its andesitic flows) and the underlying basement were subjected to layer-parallel shortening or contraction (Stage VI). This is mainly expressed by development of beddingnormal pressure-solution cleavage and shear fractures. Cleavage spacing and shape vary with lithology. The spacing of the cleavage domains ranges from millimeters, in the less competent units, to centimeters, in the high competent units. Layerparallel shortening was accompanied by the development of a set of conjugate shear fractures.
8) The seventh recognized structural stage is an episode of folding (Stage VII). Although observed throughout the entire stratigraphic sequence of Fatima Group, Mesoscopic folds are particularly common in the middle Shubayrim Formation (middle carbonate unit). Folding was locally accompanied by development of related minor structures, such as cleavage, veins and small-scale faults. The overprinting relationship among these structures reveals that they are consequences of folding, and are formed sequentially from oldest to youngest as follows: folding, fracturing (cleaving and faulting) and veining by calcite and quartz. Folding stage could be classified into two main sub-stages; fold initiation (G1) and 
fold amplification and tightening (G2). Associated with fold initiation, the pressure-solution cleavage produced during layer-parallel shortening is locally overprinted by cleavage domains which are bedding-normal in fold hinges and oblique to bedding in fold limbs. This indicates that the latter fabrics are roughly coeval with the early stages of folding. Amplification, tightening and overturning of folding led to the formation of fold axis-normal extensional fabrics. Such fabrics overprint the earlier formed fold-related cleavage and being parallel to the layer-parallel slip lineation (flexural-slip striae) associated with flexural-slipping of bedding planes.

9) Further fold tightening led to the development of an amazing and complete thrust system in Fatima Group (Stage VIII). Thrusting started first parallel and sub-parallel to the bedding planes (thin-skinned thrusting) and continued by the formation of younger ramps oblique to the bedding (thick-skinned thrusting). Thenceforward, thrusts developed sequentially according to the "footwallnucleating footwall-vergent rule" where younger thrusts were formed in the footwalls of the earlier formed ones.

10) Immediately following thrusting or a long period of time, Wadi Fatima FAT belt was affected by a NESW (to NNE-SSW) shortening (Stage IX), resulted in open refolding of the asymmetric overturned folds and associated thrusts in a NW-SE to NNW-SSE direction. Finally, the whole Wadi Fatima District underwent NE tilting (Stage X), most probably due to the Red Sea Rifting. In between the tilted fault blocks, few exposures of Shumaysi Formation (Oligocene) were deposited. The main sedimentary units of this formation in its type locality include beds of [7] sandstone, siltstone, shale, pebbly sandstone, chert, volcanic ash, oolitic hematite; these are overlain by a basalt flow of unknown thickness and nonconformably overlie crystalline rocks.

\subsection{Effect of Basement Structures on Deformation of Fatima FAT Belt}

Although the previously proposed tectonic scenarioseems to be convincing and persuasive in the light of the available field relations, the contact separating Fatima Group from the underlying basement is debatable and enigmatic. As mentioned before, this contact is marked by the presence of a polymictic conglomeratic bed reaching up to several meters thick. The bewildering issue is that the pebbles within this bed are in most cases randomly distributed and haven't got preferred orientation, and kinematic indicators along the contact itself are completely absent. These observations indicate that the contact is passive from the tectonic point of view since the deposition of Fatima Group. Consequently, the suggestion that the sediments were transported and thrusted over the preexisting amphibolites and schists for several kilometers looks like controversial, particularly if we take into con- sideration the conclusion reached by [8] that Fatima was deposited close to a predominant granitic source area. For these reasons, it is possible to generate another scenario or tectonic model to illustrate the evolution of Wadi Fatima District. This model suggests the presence of basement ramps (pre-existing normal faults), with NW to NNW dipping, have a strong effect on overlying Fatima Group which was evolved in such case throughout gravitational, soft-sediment slumping and deformation (Figure 17). Examples of these NW to NNW-oriented preexisting normal faults were encountered in some older granitic outcrops to the north of Jabal Shubayrim. The disappearance of thrust striae and other kinematic indicators from Fatima-basement contact and the absence of preferred orientation in the pebbles could be explained by the assumption that sliding or slumping was carried out through the shale, claystone or even green siltstone of the Lower Baqqar Formation. The progressive evolution of slump systems in Wadi Fatima District can be broadly categorized into initiation, translation, cessation, relaxation and compaction phases, similar to those categories proposed by [32] in the Dead Sea Basin.

\subsection{Two-Phase Model vs Progressive Deformation?}

As mentioned before, folding and thrusting commonly exhibit close genetic relationships in foreland FAT belts [33], and their geometric and kinematic links have long been recognized [33-35]. Such relationships have been widely investigated by field, theoretical and experimental research. Overall geometries and strain distribution of natural thrust-related folds support either fold-first kinematics (break-thrust kinematics) [36-38], or thrust-first kinematics [39-41], and also contemporaneous folding and faulting kinematics [42-44]. [45] proposed a transition from initial decollement folding to thrust-tip folding, in order to prevent space problems at the lower ramp hinge where a footwall syncline generates, and to maintain a constant fault propagation to fault slip ratio (PR/SR ratio) during deformation.

In Wadi Fatima FAT belt, mesoscopic fabrics and their overprinting relationships and several lines of evidence, such as the geometry of interacting outcropand map-scale folds and thrusts, the pattern of thrust displacement variations and indications for hinge migration during fold growth, provide useful information for a better understanding of fold-thrust interaction and strongly suggest that folds and thrusts are geometrically and kinematically linked structures and that thrusting initiated as a consequence of folding; i.e. fold-first kinematics (break-thrust kinematics). However, the question of whether deformation was progressive or two-phase in character, or in other word whether folding and thrusting were formed during one phase or two distinct phases of deformation, 

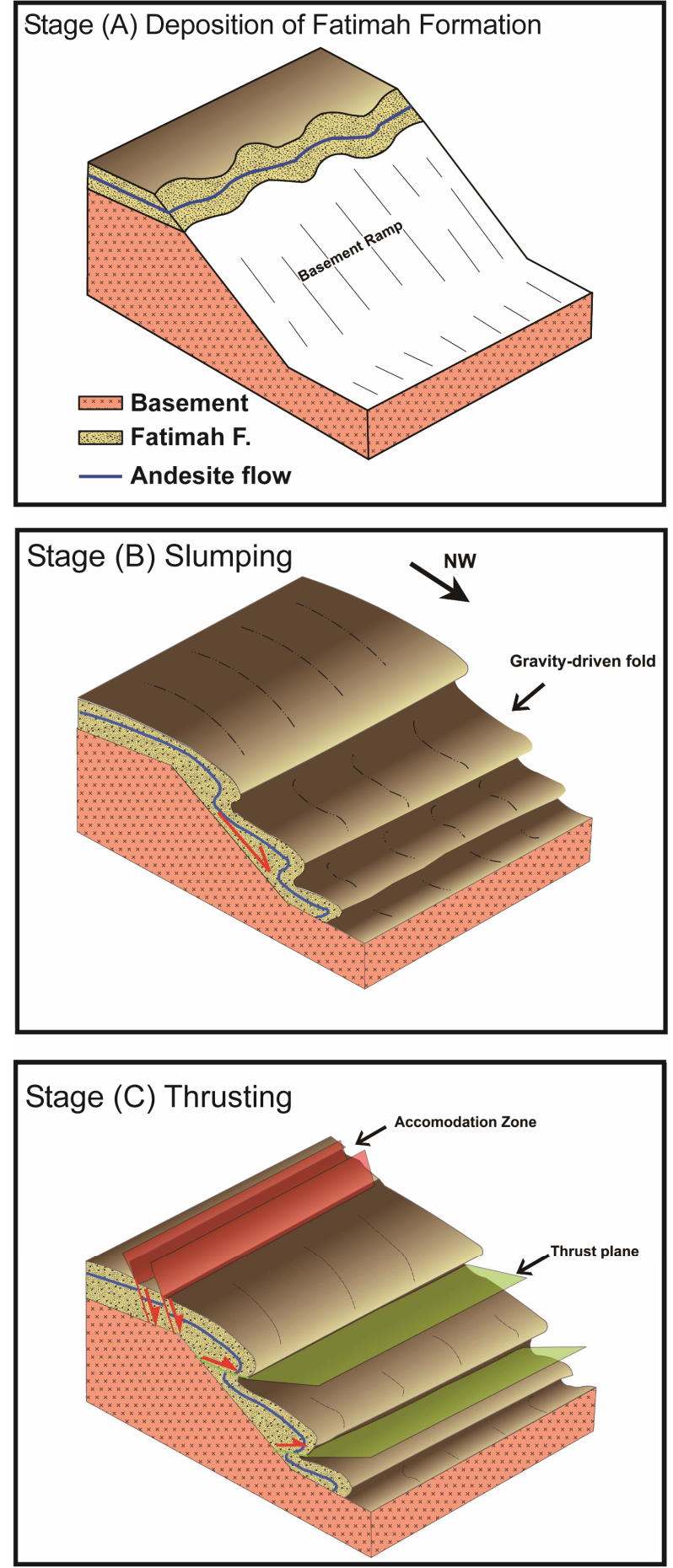

Figure 17. Tectonic evolution of Wadi Fatima FAT belt in case of the presence of basement ramps (pre-existing normal faults), with NW to NNW dipping.

remains unanswered. As a matter of fact, field observations and relations indicate a progressive deformation model, where both folds and thrusts are kinematically linked structures, produced during a single continuous phase of deformation.

\subsection{Transportation Direction of Wadi Fatima FAT Belt}

The transportation directions reported from the Neoproterozoic Pan-African belt of the ANS vary from top towards NE (e.g. [46,47], top to the NW (e.g. [48-52], top to the SE (e.g. [53], top to the SW (e.g. [54,55] and top to the W and WSW (e.g. [56-61]. In the present study area, the stretching lineations (bedding plane slickenline striae) recorded along thrust planes reveal NW to NNW transportation direction of Wadi Fatima FAT belt. The tectonic transport vector is in congruent with the mean orientation of slickenline striae formed by layer-parallel slipping along folded bedding planes. Other evidence supporting this transport direction embrace mesoscopic folding vergence (direction of overturning) towards NW and NNW direction, SE and SSE dipping of thrust ramps with decreasing in the amount of dip in the direction of NW and NNW, and diminishing of the intensity of deformation and thrust stacking and imbrication from SE to NW. It is worthy to denote that folds verge usually towards the foreland in the case of foreland FAT belts, and thrusts show a sense of movement of top-to-the-foreland, and deformation becomes younger towards the foreland with thrusts developing in a break-forward or piggy-back sequence defining a regional foreland directed tectonic transport direction. Although a dominant orientation of the tectonic transport vector prevails, in detail the sense of motion of each thrust sheet may vary in its orientation spatially and/or through time (e.g. [62]. Moreover, in few exposures the NW to NNW stretching lineations overprint attenuated older WSW stretching lineations. Such infrequently overprinting relation may point out that Wadi Fatima FAT belt underwent a WSW transportation predating the main transportation event which was towards the NW to NNW.

\section{Acknowledgements}

We wish to thank Faculty of Earth Sciences, King Abdulaziz University, for logistic support during field Program, as well as for lab facilities. Previous versions of the manuscript were improved by comments from Profs. P. Johnson, A. Fowler and anonymous reviewers.

\section{REFERENCES}

[1] R. J. Stern, “Arc Assembly and Continental Collision in the Neoproterozoic East African Orogen: Implications for the Consolidation of Gondwanaland," Annual Review of Earth and Planetary Sciences, Vol. 22, 1994, pp. 319-351. doi:10.1146/annurev.ea.22.050194.001535

[2] R. J. Stern, "Crustal Evolution in the East African Orogen: A Neodymium Isotopic Perspective,” Journal of African Earth Sciences. Vol. 34, No. 3-4, 2002, pp.109-117. doi:10.1016/S0899-5362(02)00012-X 
[3] T. M. Kusky, M. Abdelsalam, R. Stern and R. Tucker, "Preface to Special Issue on the East African and Related Orogens and the Assembly of Gondwana,” Precambrian Research. Vol. 123, 2003, pp. 81-85. doi:10.1016/S0301-9268(03)00062-7

[4] P. R. Johnson and B. Woldehaimanot, "Development of the Arabian-Nubian Shield: Perspectives on Accretion and Deformation in the Northern East African Orogen and the Assembly of Gondwana,” In: M. Yoshida, B. F. Windley and S. Dasgupta, Eds., Proterozoic East Gondwana: Supercontinent Assembly and Breakup. Geological Society of London, London, 2003, pp. 290-325.

[5] P. R. Johnson, A. Andresen, A. S. Collins, A. R. Fowler, H. Fritz, W. Ghebreab, T. M. Kusky and R. J. Stern, "Late Cryogenian-Ediacaran History of the Arabian-Nubian Shield: A Review of Depositional, Plutonic, Structural and Tectonic Events in the Closing Stages of the Northern East African Orogen," Journal of African Earth Sciences, Vol. 61, No. 3, 2011, pp. 167-232. doi:10.1016/j.jafrearsci.2011.07.003

[6] F. A. R. Zakir and A. R. Moustafa, "Structural Setting of Jabal Abu Ghurrah Area, Wadi Fatima, West Central Saudi Arabia," Journal of King Abdulaziz University: Earth Sciences, Vol. 5, 1992, pp. 177-201.

[7] A. M. S. Al-Shanti, "Oolitic Iron Ore deposits in Wadi Fatima between Jeddah and Mecca, Saudi Arabia,” Saudi Arabian Ministry of Petroleum and Mineral Resources, Directorate General of Mineral Resources, Vol. 2, No. 2, 1966, $51 \mathrm{p}$.

[8] K. Nebert, A. A. Alshaibi, M. Awlia, I. Bounny, Z. A., Nawab, O. H. Sharief, O. A. Sherbini and A. H. Yeslam, "Geology of the Area North of Wadi Fatima, Kingdom of Saudi Arabia,” Center for Applied Geology, Jeddah, Bulletin 1, 1974, No. 1, pp. 30-31.

[9] G. F. Brown and R. O. Jackson, “The Arabian Shield,” The 21st International Geological Congress, Copenhagen Vol. 9, 1960, pp. 69-77.

[10] R. Karpoff, “Observations Preliminaires Sur La Socle Ancien De I'Arabie: C. R. Somm,” Geological Society of France, 1955, pp. 105-106.

[11] H. J. Duyverman, N. B. Harria and C. J. Hawkes-worth, "Crustal Accretion in the Pan-African: Nd and Sr Isotope Evidence from the Arabian Shield," Earth Planetary Science Letter. Vol. 59, No. 2, 1982, pp.315-326. doi:10.1016/0012-821X(82)90134-0

[12] D. P. F. Darbyshire, N. J. Jackson, C. R. Ramsay and M. J. Roobol, "Rb-Sr Isotope Study of Latest Proterozoic Volcano-Sedimentary Belts in the Central Arabian Shield," Journal of Geological Society of London, Vol. 140, No. 2, 1983, pp. 203-213. doi:10.1144/gsjgs.140.2.0203

[13] T. A. Moore and M. H. Al-Rehaili, "Explanatory Notes to the Geologic Map of the Makkah Quadrangle,” Sheet 21D, Geoscience Map GM-107C, Kingdom of Saudi Arabia, Ministry of Petroleum and Mineral Resources, Directorate General of Mineral Resources, 1989.

[14] A. M. S. Al-Shanti, "Geology of the Arabian Shield of Saudi Arabia," Scientific Publishing Center, King Abdulaziz University, 2009, p.190.

[15] D. L. Grainger, “The Late Proterozoic Fatima Groupnear
Jeddah,” Geo Arabia, Vol. 6, 2001, pp.103-114.

[16] M. I. Matsah, M. H. T. Qari, A. M. Hegazi, M. A. Amlas and Z. Hamimi, "Kinematics and Progres- sive deformational history of Al-Jamoom Pan-Af- rican belt, Western Arabian Shield, Saudi Arabia," Annals of Geological Survey of Egypt, Vol. 28, 2005, pp. 111-131.

[17] W. R. Greenwood, D. G. Hadley, R. E. Anderson, R. J., Fleck and D. L. Schmidt, "Late Proterozoic Cratonization in Southwestern Saudi Arabia,” Philosophical Transactions of The Royal Society of London A, Vol. 280, No. 1298, 1976, pp. 517-527. doi:10.1098/rsta.1976.0010

[18] J. Delfour, "Geology and Mineralization of the Northern Arabian Shield,” DMMR Open File Report, 1982, pp. 230.

[19] S. Khomsi, A. Smadi, M. Matsah and M. El-Shafei, "Structural Style of the Wadi Fatima Area in Eastern Jeddah on the Border of the Arabian Shield: Insightful Thrust Mechanisms,” Arabian Conference of Geosciences, 2011.

[20] G. F. Brown, R. O. Jackson, R. G. Bogue and W. H. Maclean, "Geologic Map of the Southern Hijaz Quadrangle KSA,” US Geological Survey Miscellaneous Geological Investigation, 1962, Map I-210A.

[21] R. Karpoff, "Sur l' Existence Du Maestrichtien Au Nord De Djeddah Arabie Se'oudite," Comptes Rendus de l'Académie des Sciences, Vol. 245, 1957, pp. 1322-1324.

[22] M. C. A. Powell, “A Morphological Classification of Rock Cleavage,” Tectonophysics, Vol. 58, No. 1-2, 1979, pp. 21-34. doi:10.1016/0040-1951(79)90320-2

[23] G. J. Borradaile, M. B. Bayly and C. M. A. Powell, "Atlas of Deformational and Metamorphic Rock Fabrics," 1982, Springer-Verlag, Berlin Heidelberg New York doi:10.1007/978-3-642-68432-6

[24] Z. Hamimi, E. K. El-Sawy, A. S. El-Fakharani, A. Shujoon, M. Matsah and M. El-Shafei, "Structural Evolution of the NE-Trending 620-540 Ma Ad-Damm Shear Zone, Arabian Shield, Saudi Arabia,” European Geosciences Union, Munich, 2012.

[25] S. El-Gaby, F. K. List and R. Tehrani, "Geology, Evolution and Metallogenesis of the Pan-African Belt in Egypt,” In: S. El-Gaby and R. O. Greiling, Eds., The Pan-African Belt of Northeast Africa and Adjacent Areas: Tectonic Evolution and Economic Aspects of a Late Proterozoic Orogen, Vieweg and Sohn. Braunschweig, Wiesbaden, 1988, pp.17-65.

[26] B. A. Van Der Pluijm and S. Marshak, "Earth Structure," 2nd Edition, Norton Publication House, New York, 2004.

[27] J. Poblet and R. J. Lisle, "Kinematic Evolution and Structural Styles of Fold-And-Thrust Belts," Geological Society of London, Vol. 349, 2011, pp. 1-24.

[28] J. Casey Moore and E. A. Silver, "Continental Margin Tectonics: Submarine Accretionary Prisms," Review of Geophysics, Vol. 25, No. 6, 1987, pp. 1305-1312. doi:10.1029/RG025i006p01305

[29] R. Von Huene and D. W. Scholl, “Observations at Convergent Margins Concerning Sediment Subduction, Subduction Erosion, and the Growth of Continental Crust," Review of Geophysics, Vol. 29, No. 3, 1991, pp. 279-316. 


\section{doi:10.1029/91RG00969}

[30] M. P. Coward, “Thrust Tectonics, Thin-Skinned or ThickSkinned and the Continuation of Thrusts to Deep in the Crust,” Journal of Structural Geology, Vol. 5, No. 2, 1983, pp. 113-125. doi:10.1016/0191-8141(83)90037-8

[31] H. Fossen, "Structural Geology,” Cambridge University Press, Cambridge, 2010. doi:10.1017/CBO9780511777806

[32] G. I. Alsop and S. Marco, "Soft-Sediment Deformation within Seismogenic Slumps of the Dead Sea Basin," Journal of Structural Geology, Vol. 33, No. 4, 2011, pp. 433-457. doi:10.1016/j.jsg.2011.02.003

[33] C. D. A. Dahlstrom, "Balanced Cross-Sections," Canadian Journal of Earth Sciences Vol. 6, No. 4, 1969, pp. 743-757. doi:10.1139/e69-069

[34] J. L. Rich, "Mechanics of Low-Angle Overthrust Faulting as Illustrated by Cumberland Thrust Block, Virginia, Kentucky, and Tennessee," American Association of Petroleum Geology Bulletin, Vol. 18, No. 12, 1934, pp. 15841596.

[35] J. Dennis, “Structural Geology,” John \& Wiley, New York, 1972.

[36] N. B. Woodward, "Deformation Styles and Geometric Evolution of Some Idaho-Wyoming Thrust Belt Structures,” In: S. Mitra and G. W. Fisher, Eds., Structural Geology of Fold and Thrust Belts, Johns Hopkins University Press, Baltimore, 1992, pp. 191-206.

[37] D. M. Fisher and D. J. Anastasio, "Kinematic Analysis of a Large Scale Leading Edge Fold, Lost River Range, Idaho," Journal of Structural Geology, Vol. 16, 1994, pp. 337-354. doi:10.1016/0191-8141(94)90039-6

[38] C. K. Morley, "Fold-Generated Imbricates: Examples from the Caledonides of Southern Norway,” Journal of Structural Geology, Vol. 16, No. 5, 1994, pp. 619-631. doi:10.1016/0191-8141(94)90114-7

[39] J. Suppe, "Geometry and Kinematics of Fault-Bendfolding,” American Journal of Science, Vol. 283, No. 7, 1983, pp. 684-721. doi:10.2475/ajs.283.7.684

[40] D. Medwedeff, "Growth Fault-Bend Folding at Southeast Lost Hills, San Joaquin Valley, California,” AAPG Bulletin: American Association of Petroleum Geologists, Vol. 73, No. 1, 1989, pp. 54-67.

[41] W. R. Jamison and A. Pope, "Geometry and Evolution of a Fault-Bend Fold: Mount Bertha Anticline,” Bulletin of Geological Society of America, Vol. 108, No. 2, 1996, pp. 208-224. doi:10.1130/0016-7606(1996)108<0208:GAEOAF>2.3.C $\underline{\mathrm{O} ; 2}$

[42] J. L. Alonso and A. Teixell, "Forelimb Deformation in Some Natural Examples of Fault-Propagation Folds,” In: K. R. McClay, Ed., Thrust Tectonics, Chapman and Hall, London, 1992, pp. 175-180. doi:10.1007/978-94-011-3066-0_15

[43] B. A. Couzens and W. M. Dunne, "Displacement Transfer at Thrust Terminations: The Saltville Thrust and Sinking Creek anticline, Virginia, U.S.A,” Journal of Structural Geology, Vol. 16, No. 8, 1994, pp. 781-793. doi:10.1016/0191-8141(94)90145-7
[44] E. Tavarnelli, "Evidences for Fault-Propagation Folding in the Umbria-Marche-Sabina Apennines (Central Italy)," Annales Tectonicae, Vol. 7, 1994, pp. 87-99.

[45] M. A. McNaught and G. Mitra, "A Kinematic Model for the Origin of Footwall Synclines,” Journal of Structural Geology, Vol. 15, No. 6, 1993, pp. 805-808. doi:10.1016/0191-8141(93)90064-H

[46] R. M. El-Bayoumi and R. O. Greiling, "Tectonic Evolution of a Pan-African Plate Margin in Southeastern Egypt: A Suture Zone Overprinted by Low Angle Thrusting,” In: J. Klerkx and J. Michot, Eds., African Geology, Tervuren, 1984, pp. 47-56.

[47] M. A. Abd-Elwahed, "Thrusting and Transpressional Shearing in the Pan-African Nappe Southwest ElSibai Core Complex, Central Eastern Desert, Egypt,” Journal of African Earth Sciences, Vol. 50, No. 1, 2008, pp. 16-36. doi:10.1016/j.jafrearsci.2007.09.005

[48] R. O. Greiling, "Directions of Pan-African Thrusting in the Eastern Desert of Egypt Derived from Lineation and Strain Data. In: G. Matheis and H. Schandelmeier, Eds., Current Research in African Earth Sciences, Balkema, Rotterdam, 1987, pp. 83-86.

[49] R. O. Greiling, M. M. Abdeen, A. A. Dardir, H. El-Akhal, M. F. El-Ramly, G. M. Kamal El-Din, A. F. Osman, A. A. Rahwan, A. A. Rice and M. F Sadek, "A Structural Synthesis of the Proterozoic Arabian Nubian Shield in Egypt," Geologische Rundschau, Vol. 83, No. 3, 1994, pp. 484501. doi:10.1007/BF01083222

[50] A. Fowler and B. El-Kalioubi, “The Migif-Hafafit Gneissic Complex of the Egyptian Eastern Desert: Fold Interference Patterns Involving Multiply Deformed Sheath Folds," Tectonophysics, Vol. 346, No. 3-4, 2002, pp. 247 275. doi:10.1016/S0040-1951(01)00259-1

[51] A. Fowler, K. G. Ali, S. M. Omar and H. Eliwa, "The Significance of Gneissic Rocks and Synmagmatic Extensional Ductile Shear Zones of the Barud Area for the Tectonics of the North Eastern Desert, Egypt,” Journal of African Earth Sciences, Vol. 46, No. 3, 2006, pp. 201-220. doi:10.1016/j.jafrearsci.2006.04.011

[52] A. Fowler, H. Khamees and H. Dowidar, "El-Sibai Gneissic Complex, Central Eastern Desert, Egypt: Folded Nappes and Synkinematic Gneissic Granitoid Sheets Not a Core Complex,” Journal of African Earth Sciences, Vol. 49, No. 4-5, 2007, pp. 119-135. doi:10.1016/j.jafrearsci.2007.08.004

[53] G. M. Kamal El-Din, A. A. Khudeir and R. O. Greiling, "Tectonic Evolution of a Pan-African Gneiss Culmination, Gabal El Sibai Area, Central Eastern Desert. Egypt,” Zbl. Geologisch-Paliiontologischer, Vol. 1991, No. 11, 1992, pp. 2637-2640.

[54] M. M. Abdeen, M. G. Abdelsalam, H. M. Dowidar and A. A. Abdelghaffar, "Varying Structural Style along the Neo-Proterozoic Allaqi-Heiani Suture, Southern Egypt," In: E. Jadida, Ed., The 19th Colloquium of African Geology, Morocco, 2002.

[55] M. G. Abdelsalam, M. M. Abdeen, H. M. Dowidar, R. J. Stern and A. A. Abdelghaffar, "Evolution of the Neoproterozoic Allaqi-Heiani Suture Zone, Southern Egypt," 
Precambrian Research, Vol. 124, No. 1, 2003, pp. 87-104. doi:10.1016/S0301-9268(03)00080-9

[56] M. L. Abdel-Khalek, M. A. Takla, A. Sehim, Z. Hamimi and A. W. El-Manawi, "Geology and Tectonic Evolution of Wadi Beitan Area, South Eastern Desert, Egypt," Geology of Arab World, Vol. 1, 1992, pp. 369-393.

[57] M. L. Abdel-Khalek, M. A. Takla, A. Sehim, M. Abdel Wahed, Z. Hamimi and S. Sakran, "Geology and Tectonic Evolution of the Shield Rocks, East Wadi Beitan Area, Southeastern Desert, Egypt," Egyptian Journal of Geology, Vol. 43, No. 1, 1999, pp.1-15.

[58] E. Wallbrecher, H. Fritz, A. A. Khudeir and F. Farhad, "Kinematics of Pan-African Thrusting and Extension in Egypt,” In: U. Thorweihe and H. Schandelmeier, Eds., Geoscientific Research in Northeast Africa. Balkema, Rotterdam, 1993, pp. 7-30.

[59] Z. Hamimi, M. A. El-Amawy and M. Wetait, “Geology and Structural Evolution of El-Shalul Dome and Environs,
Central Eastern Desert, Egypt,” Egyptian Journal of Geology, Vol. 38, 1994, pp. 575-595.

[60] Z. Hamimi, M. El-Shafei, G. Kattu and M. Matsah, "Transpressional Regime in Southern Arabian Shield: Insights from Wadi Yiba Area, Saudi Arabia," Gondwana Collision (Special Publication, Mineralogy and Petrology), 2011.

[61] G. A. H. Kattu, "Structural Evolution of Wadi Yiba Area, Southern Arabian Shield, Saudi Arabia,” M.Sc. Thesis, King Abdulaziz University, Jeddah, 2011.

[62] J. L. Simón, and C. L. Liesa, "Incremental Slip History of a Thrust: Diverse Transport Directions and Internal Folding of the Utrillas Thrust Sheet (NE Iberian Chain, Spain)," Geological Society of London, Vol. 349, 2011, pp. 77-97. doi:10.1144/SP349.5 